\title{
The Road so Far in Colorectal Cancer Pharmacogenomics: Are We Closer to Individualised Treatment?
}

\author{
Ana Rita Simões ${ }^{1,2,+} \mathbb{D}$, Ceres Fernández-Rozadilla ${ }^{1,2, *,+} \mathbb{D}$, Olalla Maroñas ${ }^{1}$ and \\ Ángel Carracedo 1,2,3,4 \\ 1 Grupo de Medicina Xenómica, Universidade de Santiago de Compostela (USC), \\ 15706 Santiago de Compostela, Spain; anarita.santos.simoes@rai.usc.es (A.R.S.); \\ olalla.maronas@usc.es (O.M.); angel.carracedo@usc.es (Á.C.) \\ 2 Instituto de Investigación Sanitaria de Santiago (IDIS), 15706 Santiago de Compostela, Spain \\ 3 Fundación Pública Galega de Medicina Xenómica; SERGAS, 15706 Santiago de Compostela, Spain \\ 4 Consorcio Centro de Investigación Biomédica en Red de Enfermedades Raras-CIBERER, \\ 28029 Madrid, Spain \\ * Correspondence: ceres.fernandez.rozadilla@gmail.com \\ + These authors contributed equally to this work.
}

Received: 13 October 2020; Accepted: 17 November 2020; Published: 19 November 2020

\begin{abstract}
In recent decades, survival rates in colorectal cancer have improved greatly due to pharmacological treatment. However, many patients end up developing adverse drug reactions that can be severe or even life threatening, and that affect their quality of life. These remain a limitation, as they may force dose reduction or treatment discontinuation, diminishing treatment efficacy. From candidate gene approaches to genome-wide analysis, pharmacogenomic knowledge has advanced greatly, yet there is still huge and unexploited potential in the use of novel technologies such as next-generation sequencing strategies. This review summarises the road of colorectal cancer pharmacogenomics so far, presents considerations and directions to be taken for further works and discusses the path towards implementation into clinical practice.
\end{abstract}

Keywords: colorectal cancer; adverse drug reactions; pharmacogenomics; personalised medicine; toxicity

\section{Introduction}

Colorectal cancer (CRC) is the second leading cause of cancer-related death and the third most commonly diagnosed cancer [1]. Surgical resection is the preferable treatment independently of stage, but chemotherapy is widely used too across stages. There are different chemotherapeutic schemes for CRC treatment (Table 1).

Table 1. Guidelines for colorectal cancer (CRC) treatment.

\begin{tabular}{ccc}
\hline \multirow{2}{*}{ CRC Stage } & \multicolumn{2}{c}{ Treatment } \\
\cline { 2 - 3 } & Surgery & Pharmacological Treatment \\
\hline I & Wide surgical resection and anastomosis & No adjuvant chemotherapy recommended \\
\hline II & Wide surgical resection and anastomosis & $\begin{array}{c}\text { Adjuvant chemotherapy for high-risk could } \\
\text { be considered }\end{array}$ \\
\hline
\end{tabular}


Table 1. Cont.

\begin{tabular}{|c|c|c|}
\hline \multirow{2}{*}{ CRC Stage } & \multicolumn{2}{|r|}{ Treatment } \\
\hline & Surgery & Pharmacological Treatment \\
\hline III & Wide surgical resection and anastomosis & $\begin{array}{c}\text { Adjuvant administration of oxaliplatin plus 5-FU } \\
\text { or capecitabine }\end{array}$ \\
\hline \multirow[t]{2}{*}{ IV } & \multirow{2}{*}{$\begin{array}{c}\text { The majority of patients have metastases } \\
\text { that initially are not suitable for } \\
\text { potentially curative resection. } \\
\text { Revaluate after chemotherapy }\end{array}$} & $\begin{array}{l}\text { Cytotoxic agents: } \\
\text { 1st line: 5-FU or capecitabine alone or in combination } \\
\text { either with oxaliplatin or irinotecan } \\
\text { 2nd line: if refractory to irinotecan-based treatment, } \\
\text { FOLFOX is recommended; and if refractory to } \\
\text { oxaliplatin-based treatment, } \\
\text { FOLFIRI is recommended }\end{array}$ \\
\hline & & $\begin{array}{c}\text { Biological targeted agents: } \\
\text { 1st line: monoclonal antibodies against VEGF } \\
\text { (bevacizumab, aflibercept) and/or EGFR (cetuximab, } \\
\text { panitumumab), if } R A S \text { mutation excluded } \\
\text { Multi-kinase inhibitor: regorafenib }\end{array}$ \\
\hline
\end{tabular}

FOLFOX: folinic acid (leucovorin-LV) + fluorouracil + oxaliplatin; FOLFIRI: leucovorin + fluorouracil + irinotecan; VEGF: vascular endothelial growth factor; EGFR: epidermal growth factor receptor.

Usually, the first line of treatment is based on fluoropyrimidines: 5-fluorouracil (5-FU) or its oral prodrug capecitabine, either alone or in different combinations with other agents, the most common being leucovorin, oxaliplatin (named FOLFOX or XELOX -if capecitabine is used instead of 5FU) or irinotecan (FOLFIRI) [2-5]. Besides these cytotoxic agents, metastatic CRC (mCRC) treatment may in addition include biological targeted agents to improve patient outcome, such as monoclonal antibodies against vascular endothelial growth factor (VEGF) (bevacizumab), or against epidermal growth factor receptor (EGFR) (cetuximab and panitumumab) (Table 1) [4].

There are two essential factors to be taken into account when considering efficacy and appropriateness of a treatment: response and toxicity. Response is often evaluated based on overall survival, progression-free survival or response evaluation criteria in solid tumors (RECIST), in the case of unresectable CRC [6]. On the other hand, patients subject to chemotherapy are prone to develop adverse drug reactions (ADRs) that might be severe or even fatal, and have a considerable impact on healthcare and burden. These ADRs can affect the patients' quality of life (even in the long term) and may hinder treatment, due to necessary delays or dose reduction. A study with more than four thousand mCRC patients receiving FOLFOX, FOLFIRI or XELOX saw that $90 \%$ of patients had one ADR, and $66 \%$ of patients had $>1$ ADR during the first line of treatment [7]. These toxic events also come with an increased economic burden to resolve them, with haematological toxicities being the most costly to resolve, followed by respiratory, endocrine/metabolic, central nervous system and cardiovascular ones.

Since both response and toxicity events have heterogeneous distributions amongst patients, it has been hypothesised that these ADRs may be caused by underlying genetic variants. Moreover, because chemotherapy agents have only been used since the 1950s, any genomic variants having large effects on toxicity responses have not had time to be washed away by negative selection $[8,9]$. Moreover, because cancer is usually related to later stages of life and does not affect fitness, purifying selection against these variants is not in place. Therefore, it is feasible that genetic variants having moderate-to-large effects (detectable by classical association studies) could be responsible for the observed variability.

Pharmacogenetics is a science that aims to learn about the inherited inter-variability in response and ADRs after drug exposure. First-generation studies were focused on the analysis of genes with an a priori relationship to drug effect, i.e., those involved mainly in the adsorption, distribution, metabolism and excretion (ADME) of chemotherapeutic agents. Later, these studies started to apply global approaches without a previous functional hypothesis, like genome-wide association studies (GWAS). The Pharmacogenomics Knowledgebase (PharmGKB [10]) is a free database that aggregates, 
curates, integrates and disseminates the knowledge obtained from these studies regarding the impact of human genetic variation on drug response and toxicity. Other important sources of pharmacogenomic information have also launched from the efforts of The Clinical Pharmacogenetics Implementation Consortium (CPIC), which aims to create, curate and post free detailed gene/drug clinical practice guidelines (https://cpicpgx.org/ (accessed on 29 October 2020)).

In this review, we summarise the available data on CRC pharmacogenomics to date and go beyond the typically discussed candidate gene approaches, to cover genome-wide studies and next-generation sequencing. We also reflect on the necessity of comprehensive works including molecular studies to assess variant functionality, and discuss the limitations towards clinical implementation in the light of cost-effectiveness to health systems. Last but not least, we discuss considerations for further studies towards a routine implementation of personalised medicine strategies in clinical practice.

\section{Chemotherapeutic Agents in CRC Treatment}

Chemotherapy based on fluoropyrimidines, specifically 5-FU, has been used for over thirty years now, and is still the backbone of CRC treatment (Figure 1) [11]. However, there have been reports that show that up to $94 \%$ of patients treated with this drug end up developing ADRs, some of which may be severe or life threatening (Table 2) [12]. For instance, some studies have shown that around $40-56 \%$ of patients treated with 5-FU develop severe neutropenia, and 10-15\% present grade 3-4 diarrhoea [13]. Patients receiving capecitabine have a similar incidence of ADRs, although with less severe neutropenia, but present hand-foot syndrome (HFS) at a high incidence (54\%) instead (Table 2) [14].

Table 2. The most common toxicity profile of CRC treatments.

\begin{tabular}{|c|c|c|c|}
\hline Treatment & $\begin{array}{c}\text { Significant ADRs } \\
\text { (According to FDA Labels) * }\end{array}$ & $\begin{array}{l}\text { ADR Incidence } \\
\text { (\% Patients) }\end{array}$ & Ref. \\
\hline 5-Fluororacil & $\begin{array}{l}\text { Diarrhoea, neutropenia, mucositis, } \\
\text { nausea/vomiting, stomatitis, asthenia, } \\
\text { leukopenia, anaemia. }\end{array}$ & $94 \%$ & [12] \\
\hline Capecitabine & $\begin{array}{l}\text { Hand-and-foot syndrome, diarrhoea, } \\
\text { nausea/vomiting, abdominal pain, fatigue, } \\
\text { hyperbilirubinemia. }\end{array}$ & $96 \%$ & [12] \\
\hline Oxaliplatin & $\begin{array}{l}\text { Peripheral sensory neuropathy, } \\
\text { neutropenia, thrombocytopenia, anaemia, } \\
\text { nausea/vomiting, increase in } \\
\text { transaminases and alkaline phosphatase, } \\
\text { diarrhoea, fatigue, stomatitis. }\end{array}$ & $>92 \%$ & [15] \\
\hline Irinotecan & $\begin{array}{l}\text { Nausea/vomiting, diarrhoea, neutropenia, } \\
\text { alopecia, abdominal pain, constipation, } \\
\text { anorexia, leukopenia, anaemia, asthenia, } \\
\text { fever, body weight decreasing. }\end{array}$ & $100 \%$ & [16] \\
\hline Cetuximab & $\begin{array}{c}\text { Cutaneous adverse reactions, headache, } \\
\text { diarrhoea, infection. }\end{array}$ & $>87 \%$ & [17] \\
\hline Panitumumab & $\begin{array}{l}\text { Skin rash, paronychia, fatigue, } \\
\text { nausea, diarrhoea. }\end{array}$ & $>90 \%$ & [18] \\
\hline Bevacizumab & $\begin{array}{l}\text { Haemorrhage, hypertension, headache, } \\
\text { rhinitis, proteinuria, taste alteration, } \\
\text { dry skin, lacrimation disorder, back pain, } \\
\text { exfoliative dermatitis. }\end{array}$ & $>60 \%$ & [19] \\
\hline
\end{tabular}

* According to Food and Drug Administration (FDA) label section: Warnings and Precautions, Contraindications, and Boxed Warning Sections of Labelling for Human Prescription Drug and Biological Products. 


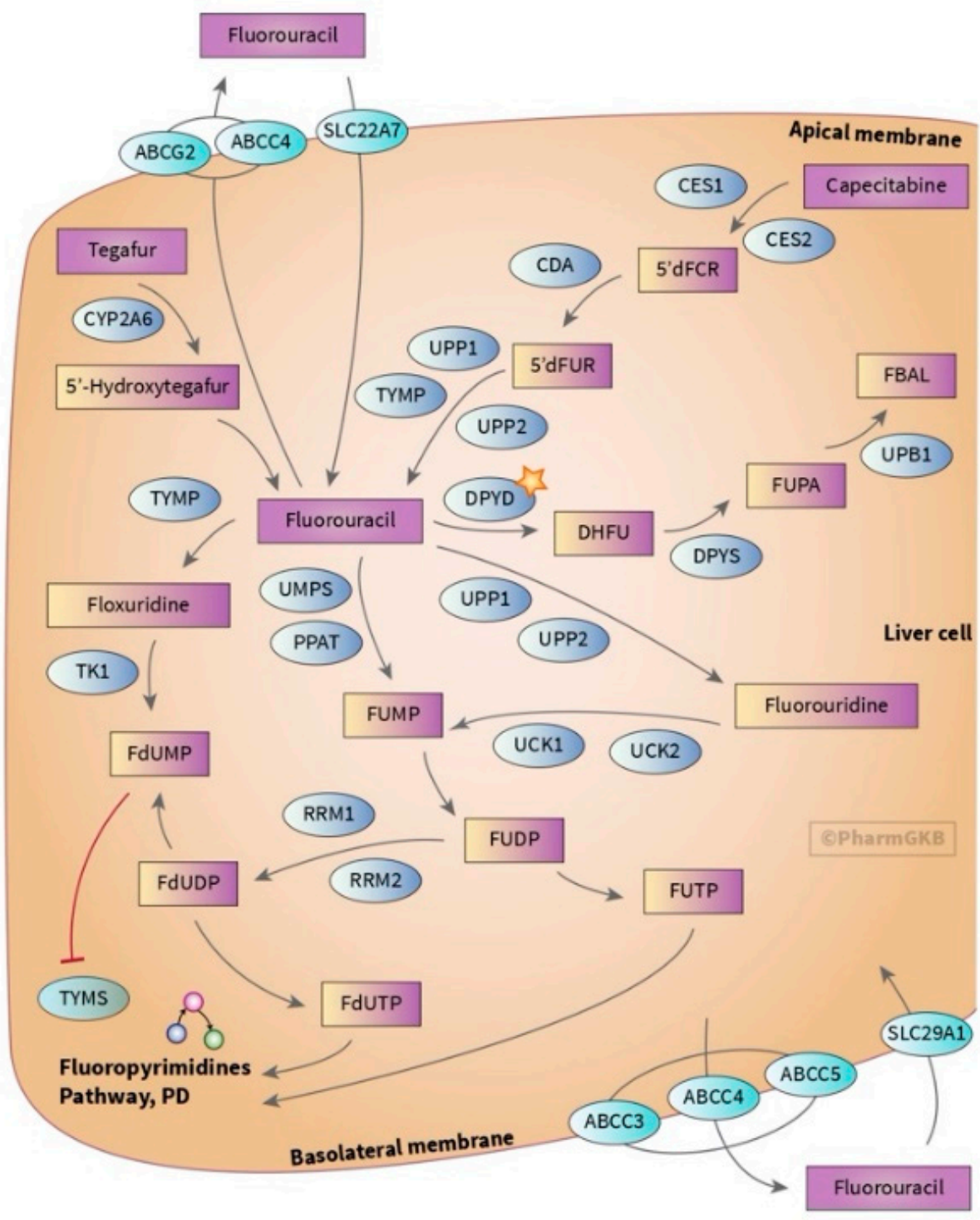

Figure 1. Graphic scheme of the genes involved in the adsorption, distribution, metabolism and excretion (ADME) of fluoropyrimidines [20]. Capecitabine passes through the gut wall and is metabolised into 5-deoxyfluorocytidine (5' dFCR) and 5'-deoxy-5-fluorouridine (5'dFUR) by carboxyl esterases (CES) and cytidine deaminase (CDA), respectively, and activated into 5-FU by thymidine phosphorylase (TP). - 5-FU is metabolised mostly in the liver by dihydropyrimidine dehydrogenase (DPD) $(<80 \%)$ into dihydrofluorouracil (DHFU). The secondary elimination pathway is through urinary excretion or catabolism in extrahepatic tissues [21]. Its mechanism of action involves the methylenetetrahydrofolate reductase (MTHFR) — converting 5,10-methylentetrahydrofolate (5,10-MTHF) into 5-MTHF, which is required for purine and thymidine synthesis, and thymidylate synthase (TS) enzymes-forming a complex with 5,10-MTHF and deoxyuridine monophosphate (dUMP), which in the end disrupts DNA replication and repair. Used with PharmGKB and Stanford University permission (available at https://www.pharmgkb.org/pathway/PA150653776 (accessed on 24 September 2020)).

Platinum-based drugs, mainly oxaliplatin, are cytotoxic agents that prevent neoplastic proliferation, by forming DNA-platinum adducts, which block replication and transcription and induce apoptosis (Figure 2) (Table 1) [22]. The main oxaliplatin dose-limiting toxicity is neuropathy, occurring in about $>90 \%$ of treated patients (Table 2) [15]. 


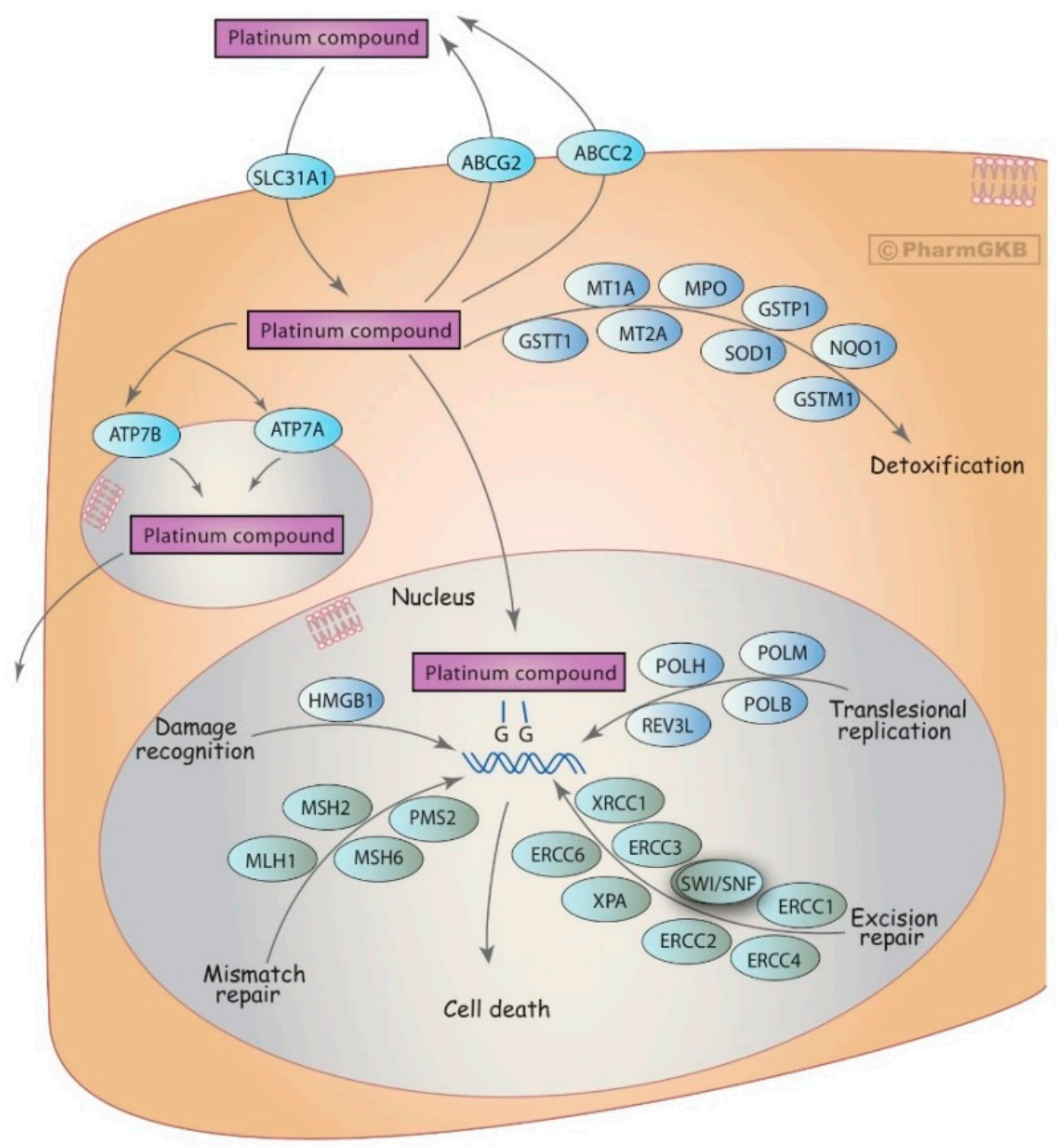

Figure 2. Graphic scheme of the genes involved in the ADME of platinum compounds, including oxaliplatin [23]. The glutathione S-transferases (GSTs), a multigene family of enzymes, undertake oxaliplatin detoxification. The solute carriers (SLCs) and adenosine-triphosphate binding cassette (ABC) transporters are responsible for oxaliplatin uptake and efflux in the liver, respectively, and so impact on drug bioavailability and toxicity profile. Further, the nucleotide excision repair (NER) and base excision repair (BER) pathways, which include the ERCC1 and ERCC2, and XRCC1 proteins, respectively, repair the damages cause by this drug. Used with PharmGKB and Stanford University permission (available at https://www.pharmgkb.org/pathway/PA150642262 (accessed on 24 September 2020)).

Irinotecan (CPT-11) is another cytotoxic agent used in the treatment of CRC in combination with 5-FU (FOLFIRI) (Table 1). FOLFIRI treatments result in better response rates and longer progression-free survival and overall survival of mCRC patients (Figure 3) [2,24]. CPT-11 is a semi-synthetic soluble analogue of the natural alkaloid camptothecin $[25,26]$. Some clinical trials report an ADR incidence for this drug of up to $100 \%$ of patients, where common ADRs include diarrhoea, neutropenia and alopecia (Table 2) [16]. 


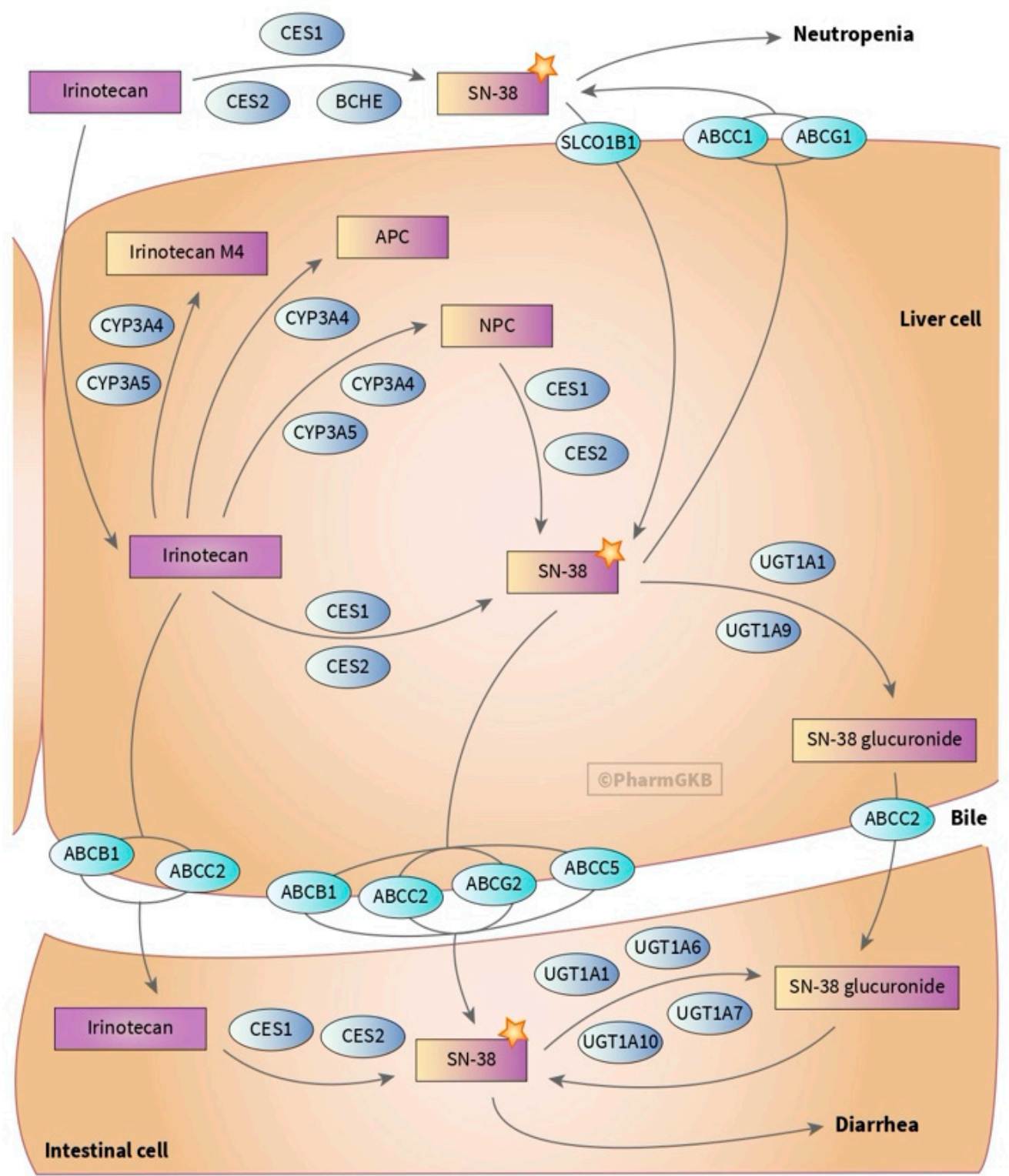

Figure 3. Graphic scheme of the genes involved in the ADME of irinotecan [10]. Irinotecan is converted into SN-38 by CES, which inhibits topoisomerase I, an enzyme essential for DNA replication and then into inactive SN-38G by UGTs. Further, it can suffer oxidation into 7-ethyl-10-[4-N-(5-aminopentanoic acid)-1-piperidino] carbonyloxycamptothecin (APC), M4 and 7-ethyl-10-[4-(1-piperidino)-1-amino] carbonyloxycamptothecin (NPC) by CYP3A4 and CYP3A5. NPC can be reactivated by CES into SN-38. Irinotecan and its metabolites' uptake and efflux are conducted by SLCs and ABC transporters, respectively. Used with PharmGKB and Stanford University permission (available at https://www. pharmgkb.org/pathway/PA2001 (accessed on 24 September 2020)). 
In case of unresectable CRC, patients may also be given biological targeted agents. Cetuximab and panitumumab bind specifically to the human EGFR protein, which is constitutively expressed in normal epithelial tissues and overexpressed in some cancers like CRC. Some of the pioneer pharmacogenetics studies on treatment efficacy found, however, that because $R A S$ mutations can constitutively activate the response pathway downstream from EGFR, anti-EGFR therapy efficacy is limited to patients' wild type for KRAS and NRAS [4]. These belong to signalling pathways downstream of EGFR, and mutations in these genes may cause EGFR-independent pathway activation, leading to resistance to anti-EGFR treatments [27]. More than $87 \%$ of patients receiving cetuximab develop an ADR and are commonly $(>25 \%)$ prone to develop cutaneous reactions, headache, diarrhoea and infection, whereas patients receiving panitumumab $(>20 \%)$ will probably have cutaneous reactions, fatigue, nausea and diarrhoea $[17,18,25,26]$. On the other hand, bevacizumab binding to VEGF blocks the interactions with its receptors on the endothelial cell surface. This interaction allows cell proliferation and angiogenesis, and thus bevacizumab reduces microvascular growth and inhibits metastatic progression. Over $60 \%$ of patients receiving bevacizumab develop ADRs, where the most common are hypertension, proteinuria, mucosal bleeding and wound healing problems $[4,19]$.

\section{Pharmacogenetics: Candidate Gene Studies}

As we mentioned before, pharmacogenetic studies arose in the context of studying the genetic factors that contribute to ADRs. Initial efforts utilised candidate gene approaches to inspect mainly genetic variation in genes that might have a great influence on the drug pharmacokinetics and pharmacodynamics, and that can alter drug concentration levels, leading to toxicity.

\subsection{Dihydropyrimidine Dehydrogenase (DPYD)}

DPD, encoded by the DPYD gene, is responsible for the vast majority of 5-FU hepatic metabolism and is responsible for the first step and rate-limiting factor in the 5-FU catabolic pathway (Figure 1). Several single nucleotide polymorphisms (SNPs) have so far been identified in this gene in association with different toxicities [28]. The most studied DPYD variant is rs3918290 (DPYD*2A, IVS14+1G>A), which causes exon 14 skipping and results in a truncated and catalytically inactive protein $[29,30]$. A study by Toffoli et al. on 603 patients treated with 5-FU-based chemotherapy reported the association of rs3918290 (OR $=8.5, p=0.008)$, $\mathrm{rs} 67376798(\mathrm{OR}=7.8, p=0.012)$ and $\mathrm{rs} 558866062(\mathrm{OR}=6.0, p=0.131)$ with general toxicity (Table 3) [28]. 
Table 3. Summary of CRC pharmacogenomics.

\begin{tabular}{|c|c|c|c|c|c|c|c|c|c|}
\hline Drug & Gene & SNP (rsID) & Change & $\begin{array}{c}\text { Alternative } \\
\text { Nomenclature }\end{array}$ & $\begin{array}{l}\text { Frequency of } \\
\text { Risk Allele }\end{array}$ & Associated ADR & OR $(95 \% \mathrm{CI})$ & $\begin{array}{l}\text { Evidence } \\
\text { Level }^{b}\end{array}$ & Ref. \\
\hline & \multirow{14}{*}{$D P Y D$} & rs55886062 & $\begin{array}{l}\text { NM_000110.3:c.1679T>G; } \\
\text { NP_000101.2:p.Ile560Ser }\end{array}$ & $D P Y D^{*} 13$ & $3 \times 10^{-4}(\mathrm{C})$ & Global toxicity & $6.0(0.6-61)$ & $1 \mathrm{~A}$ & [28] \\
\hline & & rs3918290 & $\begin{array}{l}\text { NM_000110.4:c.1905+1G>A } \\
\text { (Splice donor) }\end{array}$ & $D P Y D^{*} 2 \mathrm{~A}$ & $0.007(\mathrm{~T})$ & Global toxicity & $8.5(1.8-40.9)$ & $1 \mathrm{~A}$ & [29] \\
\hline & & rs67376798 & $\begin{array}{l}\text { NM_000110.3:c.2846A>T; } \\
\text { NP_000101.2:p.Asp949Val }\end{array}$ & & $0.003(\mathrm{~A})$ & Global toxicity & $7.8(1.6-39.2)$ & $1 \mathrm{~A}$ & [31] \\
\hline & & rs115232898 & $\begin{array}{l}\text { NM_000110.3:c.557A>G; } \\
\text { NP_000101.2:p.Tyr186Cys }\end{array}$ & & $\begin{array}{l}0.002(\text { Afr: } \\
0.023)(C)\end{array}$ & $\begin{array}{c}\text { Neutropenia, } \\
\text { mucositis, alopecia }\end{array}$ & - & $1 \mathrm{~A}$ & [32] \\
\hline & & rs75017182 & $\begin{array}{l}\text { NM_000110.4:c.1129-5923C>G } \\
\text { (Intronic) }\end{array}$ & & $0.013(\mathrm{C})$ & Global toxicity & $6.8(2.0-23)$ & $1 \mathrm{~A}$ & [33] \\
\hline & & rs56038477 & $\begin{array}{l}\text { NM_000110.3:c.1236G>A; } \\
\text { NP_000101.2:p.Glu412= }\end{array}$ & & $0.014(\mathrm{~T})$ & $\begin{array}{l}\text { Gastrointestinal; } \\
\text { haematological }\end{array}$ & $\begin{array}{l}2.0(1.5-2.8) \\
2.8(1.2-3.7)\end{array}$ & 3 & [34] \\
\hline & & rs72549303 c & $\begin{array}{l}\text { NM_000110.4:c.1898del; } \\
\text { NP_000101.2:p.Pro633fs }\end{array}$ & $D P Y D^{*} 3$ & NA & NA & NA & $1 \mathrm{~A}$ & [31] \\
\hline & & rs72549309 c & $\begin{array}{l}\text { NM_000110.4:c.295_298TCAT } \\
\text { [1]; NP_000101.2:p.Phe100fs }\end{array}$ & $D P Y D^{* 7}$ & $\begin{array}{c}6 \times 10^{-5} \\
(\text { delATGA) }\end{array}$ & NA & NA & $1 \mathrm{~A}$ & [31] \\
\hline \multirow{6}{*}{ Fluoropyrimidines } & & rs1801266 c & $\begin{array}{l}\text { NM_000110.4:c.703C>T; } \\
\text { NP_000101.2:p.Arg235Trp }\end{array}$ & $D P Y D * 8$ & $3 \times 10^{-5}(\mathrm{~A})$ & NA & NA & $1 \mathrm{~A}$ & [31] \\
\hline & & rs1801268 c & $\begin{array}{l}\text { NM_000110.4:c.2983G>T; } \\
\text { NP_000101.2:p.Val995Phe }\end{array}$ & $D P Y D^{*} 10$ & NA & NA & NA & $1 \mathrm{~A}$ & [31] \\
\hline & & rs78060119 & $\begin{array}{l}\text { NM_000110.3:c.1156G>T; } \\
\text { NP_000101.2:p.Glu386Ter }\end{array}$ & $D P Y D * 12$ & $8 \times 10^{-6}(\mathrm{~A})$ & $\begin{array}{c}\text { Leucopenia, } \\
\text { thrombocytopenia, } \\
\text { mucositis }\end{array}$ & NA & $1 \mathrm{~A}$ & [35] \\
\hline & & rs2297595 & $\begin{array}{l}\text { NM_000110.3:c.496A>G; } \\
\text { NP_000101.2:p.Met166Val }\end{array}$ & & $0.085(\mathrm{C})$ & Global toxicity & $5.9(1.3-27.2)$ & 3 & [36] \\
\hline & & rs1801265 & $\begin{array}{l}\text { NM_000110.3:c.85T>C; } \\
\text { NP_000101.2:p.Cys29Arg }\end{array}$ & $D P Y D^{* 9 A}$ & $0.228(\mathrm{G})$ & Diarrhoea & $0.8(0.7-1)$ & 3 & [37] \\
\hline & & rs 1801267 c & $\begin{array}{l}\text { NM_000110.4:c.2657G >A; } \\
\text { NP_000101.2:p.Arg886His }\end{array}$ & $D P Y D^{* 9 B}$ & $1 \times 10^{-4}(\mathrm{~T})$ & NA & NA & NA & [38] \\
\hline
\end{tabular}


Table 3. Cont

\begin{tabular}{|c|c|c|c|c|c|c|c|c|c|}
\hline Drug & Gene & SNP (rsID) & Change & $\begin{array}{l}\text { Alternative } \\
\text { Nomenclature }\end{array}$ & $\begin{array}{l}\text { Frequency of } \\
\text { Risk Allele }^{\text {a }}\end{array}$ & Associated ADR & OR $(95 \% \mathrm{CI})$ & $\begin{array}{l}\text { Evidence } \\
\text { Level }^{b}\end{array}$ & Ref \\
\hline & & rs1801159 & $\begin{array}{l}\text { NM_000110.3:c.1627A>G; } \\
\text { NP_000101.2:p.Ile543Val }\end{array}$ & $D P Y D^{* 5}$ & $0.198(C)$ & Diarrhoea & $4.9(-)$ & 3 & {$[39]$} \\
\hline & & rs1801158 & $\begin{array}{l}\text { NM_000110.3:c.1601G>A; } \\
\text { NP_000101.2:p.Ser534Asn }\end{array}$ & $D P Y D^{*} 4$ & $0.015(\mathrm{~T})$ & Global toxicity & $1.7(1.1-2.6)$ & 3 & {$[37]$} \\
\hline & & rs17376848 & $\begin{array}{l}\text { NM_000110.3:c.1896T>C; } \\
\text { NP_000101.2:p.Phe632= }\end{array}$ & & $0.051(\mathrm{G})$ & Global toxicity & $\begin{array}{c}14.5 \\
(1.4-155.2)\end{array}$ & 3 & {$[36]$} \\
\hline & & rs1801160 & $\begin{array}{l}\text { NM_000110.3:c.2194G>A; } \\
\text { NP_000101.2:p.Val732Ile }\end{array}$ & $D P Y D^{*} 6$ & $0.048(\mathrm{~T})$ & Global toxicity & $2.1(1.5-3.0)$ & 3 & {$[40]$} \\
\hline & & rs12022243 & $\begin{array}{l}\text { NM_000110.4:c.1906-14763G>A } \\
\text { (Intronic) }\end{array}$ & & $0.181(\mathrm{~T})$ & Global toxicity & $1.7(1.5-1.9)$ & 3 & {$[41]$} \\
\hline & & rs12119882 & $\begin{array}{l}\text { NM_000110.4:c.680+2545T>C } \\
\text { (Intronic) }\end{array}$ & & $0.075(\mathrm{G})$ & Hyperbilirubinemia & $4.9(1.2-20.8)$ & 3 & {$[42]$} \\
\hline & & rs76387818 & Intergenic & & $0.019(\mathrm{~A})$ & Global toxicity & $4.1(3.5-4.6)$ & 3 & {$[41]$} \\
\hline & & rs12132152 & Intergenic & & $0.020(\mathrm{~A})$ & HFS;global toxicity & $\begin{array}{l}6.1(5.5-6.8) ; \\
1.6(1.4-1.8)\end{array}$ & 3 & {$[41]$} \\
\hline & \multirow{6}{*}{ TYMS } & rs183205964 & NM_001071.4:c.-86= (5' UTR) & & $3 \times 10^{-5}(\mathrm{C})$ & Global toxicity & $3.0(1.1-8.4)$ & 3 & {$[43]$} \\
\hline & & rs2853741 & $\begin{array}{c}\text { NM_001071.4:c. (Upstream } \\
\text { transcript) }\end{array}$ & & $0.322(\mathrm{~T})$ & Diarrhoea & $0.3(0.1-0.7)$ & 3 & {$[42]$} \\
\hline & & rs699517 & $\begin{array}{c}\text { NM_017512.7:C. }{ }^{* 1289=} \\
\left(3^{\prime} \text { UTR }\right)\end{array}$ & & $0.379(\mathrm{~T})$ & $\begin{array}{c}\text { Nausea/ } \\
\text { vomiting;asthenia }\end{array}$ & $\begin{array}{l}7.9(1.5-41.6) \\
0.3(0.1-0.8)\end{array}$ & 3 & {$[42]$} \\
\hline & & rs45445694 & NM_001071.4:c. (5' UTR) & & $0.007(2 \mathrm{R} 2 \mathrm{R})$ & Global toxicity & $1.7(-)$ & 3 & {$[44]$} \\
\hline & & rs2853542 & NM_001071.4:c.-58=(5' UTR $)$ & & & $\begin{array}{l}\text { Global toxicity; } \\
\text { HFS }\end{array}$ & $\begin{array}{l}1.5(1.2-1.8) ; \\
1.4(1.2-1.8)\end{array}$ & NA & {$[45]$} \\
\hline & & rs11280056 & $\begin{array}{c}\text { NM_017512.7:c.*853_*861= } \\
\text { (3' UTR) }\end{array}$ & & & Global toxicity & $1.7(1.2-2.2)$ & NA & {$[45]$} \\
\hline & ENOSF1 & rs2612091 & $\begin{array}{c}\text { NM_017512.7:c.742-227G }>C \\
\text { (Intronic) }\end{array}$ & & $0.373(\mathrm{C})$ & Global toxicity & $1.6(1.4-1.8)$ & 3 & {$[41]$} \\
\hline
\end{tabular}


Table 3. Cont

\begin{tabular}{|c|c|c|c|c|c|c|c|c|c|}
\hline Drug & Gene & SNP (rsID) & Change & $\begin{array}{l}\text { Alternative } \\
\text { Nomenclature }\end{array}$ & $\begin{array}{l}\text { Frequency of } \\
\text { Risk Allele }^{\text {a }}\end{array}$ & Associated ADR & OR $(95 \% \mathrm{CI})$ & $\begin{array}{l}\text { Evidence } \\
\text { Level }^{b}\end{array}$ & Ref \\
\hline & \multirow{3}{*}{ UMPS } & rs2279199 & $\begin{array}{l}\text { NM_000373.4:c. (Genic } \\
\text { upstream transcript) }\end{array}$ & & $0.556(\mathrm{~T})$ & Nausea/vomiting & $0.2(0.1-1.0)$ & 3 & {$[42]$} \\
\hline & & rs4678145 & $\begin{array}{c}\text { NM_000373.4:c.156+607G>C } \\
\text { (Intronic) }\end{array}$ & & $0.096(\mathrm{C})$ & Asthenia & $4.5(1.6-13.2)$ & 3 & {$[42]$} \\
\hline & & rs1801019d & $\begin{array}{l}\text { NM_000373.4:c.638G>C; } \\
\text { NP_000364.1:p.Gly213Ala }\end{array}$ & & $0.169(\mathrm{C})$ & Global toxicity & $\begin{array}{c}17.6 \\
(1.6-195.9)\end{array}$ & 3 & {$[46]$} \\
\hline & \multirow{2}{*}{ MTHFR } & rs1801131 & $\begin{array}{l}\text { NM_001330358.1:c.1409A>C; } \\
\text { NP_001317287.1:p.Glu470Ala }\end{array}$ & & $0.289(\mathrm{G})$ & HFS & $10.0(3.8-27.8)$ & 3 & {$[47]$} \\
\hline & & rs1801133 & $\begin{array}{c}\text { NM_001330358.1:c.788C>T; } \\
\text { NP_001317287.1:p.Ala263Val }\end{array}$ & & $0.315(\mathrm{~A})$ & Neutropenia & $2.3(1.2-4.6)$ & 3 & {$[48]$} \\
\hline & TYMP & rs11479 & $\begin{array}{l}\text { NM_001113755.3:c.1412C>T; } \\
\text { NP_001244917.1:p.Ser471Leu }\end{array}$ & & $0.094(\mathrm{~A})$ & Global toxicity & $2.7(1.2-5.9)$ & 3 & {$[49]$} \\
\hline & MIR27A & rs895819 & $\begin{array}{l}\text { NR_029501.1:n.40A }>\mathrm{G} \\
\text { (Non-coding transcript) }\end{array}$ & & $0.335(\mathrm{C})$ & Global toxicity & $1.6(1.1-2.2)$ & 3 & {$[50]$} \\
\hline & $A B C C 1$ & rs7194667 & $\begin{array}{c}\text { NM_032583.4:c.1609-491A >C } \\
\text { (Intronic) }\end{array}$ & & $0.063(\mathrm{G})$ & Leucopenia & $3.31(1.3-8.7)$ & 3 & {$[51]$} \\
\hline & \multirow{3}{*}{$A B C B 1$} & rs1045642 & $\begin{array}{l}\text { NM_001348945.1:c.3645T >C; } \\
\text { NP_001335874.1:p.Ile1215= }\end{array}$ & $A B C B 1^{*} 6$ & $0.504(G)$ & HFS & NA & 3 & {$[52]$} \\
\hline & & rs2032582 & $\begin{array}{l}\text { NM_001348945.1:c.2887T>G; } \\
\text { NP_001335874.1:p.Ser963Ala }\end{array}$ & $A B C B 1^{* 7}$ & $0.637(\mathrm{C})$ & HFS & NA & 3 & {$[52]$} \\
\hline & & rs1128503 & $\begin{array}{l}\text { NM_001348945.1:c.1446T>C; } \\
\text { NP_001335874.1:p.Gly482= }\end{array}$ & $A B C B 1^{*} 8$ & $0.614(\mathrm{G})$ & Neutropenia & NA & 3 & {$[52]$} \\
\hline & \multirow{2}{*}{ SLC22A7 } & rs2270860 & $\begin{array}{l}\text { NM_006672.3:c.1269C>T; } \\
\text { NP_006663.2:p.Ser423= }\end{array}$ & & $0.368(\mathrm{~T})$ & Global toxicity & $\begin{array}{c}17.1 \\
(1.7-170.3)\end{array}$ & 3 & {$[42]$} \\
\hline & & rs4149178 & $\begin{array}{l}\text { NM_006672.3:c.1586+206A>G } \\
\text { (Intronic) }\end{array}$ & & $0.795(\mathrm{~A})$ & Diarrhoea & $0.3(0.1-0.9)$ & 3 & {$[42]$} \\
\hline
\end{tabular}


Table 3. Cont

\begin{tabular}{|c|c|c|c|c|c|c|c|c|c|}
\hline Drug & Gene & SNP (rsID) & Change & $\begin{array}{c}\text { Alternative } \\
\text { Nomenclature }\end{array}$ & $\begin{array}{l}\text { Frequency of } \\
\text { Risk Allele a }^{\text {a }}\end{array}$ & Associated ADR & OR $(95 \% \mathrm{CI})$ & $\begin{array}{l}\text { Evidence } \\
\text { Level }^{b}\end{array}$ & Ref. \\
\hline & \multirow{5}{*}{$C D A$} & rs2072671 & $\begin{array}{l}\text { NM_001785.3:c.79A>C; } \\
\text { NP_001776.1:p.Lys27Gln }\end{array}$ & & $0.279(\mathrm{C})$ & Global toxicity & $1.8(1.1-3.0)$ & 3 & [53] \\
\hline & & rs1048977 & $\begin{array}{l}\text { NM_001785.3: c.435C>T; } \\
\text { NP_001776.1:p.Thr145= }\end{array}$ & & $0.307(\mathrm{~T})$ & Hyperbilirubinemia & $8.6(1.1-70.3)$ & 3 & [42] \\
\hline & & rs602950 & $\begin{array}{c}\text { NM_001785.3:c. } \\
\text { (Upstream transcript) }\end{array}$ & & $0.224(\mathrm{G})$ & Diarrhoea & $2.3(1.3-4.2)$ & 3 & [47] \\
\hline & & rs3215400 & $\begin{array}{c}\text { NM_001785.3:c.-33_-31= } \\
\text { (5' UTR) }\end{array}$ & & 0.555 (delC) & HFS & $0.5(0.3-1.0)$ & 3 & [54] \\
\hline & & rs532545 & $\begin{array}{c}\text { NM_001785.3:c. } \\
\text { (Upstream transcript) }\end{array}$ & & $0.220(\mathrm{~T})$ & Diarrhoea & $2.3(1.3-4.2)$ & NA & [47] \\
\hline & \multirow{3}{*}{ CES1 } & rs3217164 & $\begin{array}{l}\text { NM_001025195.2:c.693+129del } \\
\text { (Intronic) }\end{array}$ & & $0.607(\mathrm{G})$ & Global toxicity & $4.1(1.8-9.0)$ & 3 & [55] \\
\hline & & rs2244614 & $\begin{array}{c}\text { NM_001025195.2:c.1171-41C>T } \\
\text { (Intronic) }\end{array}$ & & $0.482(\mathrm{G})$ & Global toxicity & $4.7(1.9-12.0)$ & 3 & [55] \\
\hline & & rs2244613 & $\begin{array}{c}\text { NM_001025195.2:c.1171-33C >T } \\
\text { (Intronic) }\end{array}$ & & $0.232(\mathrm{G})$ & Global toxicity & $6.4(1.5-27.7)$ & 3 & [55] \\
\hline & \multirow[b]{2}{*}{ CES1P1 } & rs7187684 & NR_003276.2:n. (Intronic) & & $0.278(\mathrm{~T})$ & Global toxicity & $6.5(1.5-28.0)$ & 3 & [55] \\
\hline & & rs11861118 & $\begin{array}{c}\text { NR_003276.2:n. } \\
\text { (Upstream transcript) }\end{array}$ & & $0.161(\mathrm{G})$ & Global toxicity & $6.5(1.5-28.0)$ & 3 & [55] \\
\hline & Intergenic & rs9936750 & Intergenic & & $0.161 \mathrm{C}$ & Global toxicity & $4.6(1.5-13.9)$ & 3 & [56] \\
\hline & Intergenic & rs10876844 & Intergenic & & 0.439 (A) & Diarrhoea & $6.5(1.6-27.2)$ & NA & [57] \\
\hline
\end{tabular}


Table 3. Cont

\begin{tabular}{|c|c|c|c|c|c|c|c|c|c|}
\hline Drug & Gene & SNP (rsID) & Change & $\begin{array}{c}\text { Alternative } \\
\text { Nomenclature }\end{array}$ & $\begin{array}{l}\text { Frequency of } \\
\text { Risk Allele }^{\text {a }}\end{array}$ & Associated ADR & OR $(95 \% \mathrm{CI})$ & $\begin{array}{l}\text { Evidence } \\
\text { Level }^{\mathrm{b}}\end{array}$ & Ref \\
\hline \multirow{13}{*}{ Oxaliplatin } & \multirow{4}{*}{$A B C C 2$} & rs717620 & NM_000392.5:c.-24= (5’ UTR) & & $0.171(\mathrm{~T})$ & Neuropathy & $\begin{array}{c}14.4 \\
(1.6-127.0)\end{array}$ & 3 & {$[58]$} \\
\hline & & rs3740066 & $\begin{array}{c}\text { NM_000392.5:c.3972C> } \\
\text { TNP_000383.2:p.Ile1324= }\end{array}$ & & & Neuropathy & $3.0(1.2-7.7)$ & NA & {$[58]$} \\
\hline & & rs1885301 & $\begin{array}{c}\text { NM_000392.5:c. } \\
\text { (Upstream Transcript) }\end{array}$ & & $0.413(\mathrm{~A})$ & Neuropathy & $3.1(1.4-6.9)$ & NA & {$[58]$} \\
\hline & & rs4148396 & $\begin{array}{c}\text { NM_000392.5:c.3258+56T }>C \\
\text { (Intronic) }\end{array}$ & & $0.347(\mathrm{~T})$ & Neuropathy & $4.7(1.6-13.7)$ & NA & {$[58]$} \\
\hline & $A B C G 2$ & rs3114018 & $\begin{array}{c}\text { NM_004827.3:c.-19-3415T >G } \\
\text { (Intronic) }\end{array}$ & & $0.516(\mathrm{~A})$ & Neuropathy & $2.7(1.0-4.4)$ & NA & {$[59]$} \\
\hline & GSTP1 & rs1695 & $\begin{array}{l}\text { NM_000852.3:c.313A>G; } \\
\text { NP_000843.1:p.Ile105Val }\end{array}$ & GSTP1*B & $0.339(\mathrm{G})$ & Dying & $3.0(1.2-7.6)$ & 3 & {$[60]$} \\
\hline & GSTM1 & Null genotype & - & GSTM1*0 & & Neutropenia & $2.0(1.1-3.7)$ & NA & {$[61]$} \\
\hline & GSTT1 & Null genotype & - & & & Neutropenia & $2.0(1.1-3.7)$ & NA & {$[61]$} \\
\hline & ERCC1 & rs11615 & $\begin{array}{c}\text { NM_202001.3:c.354T >C; } \\
\text { NP_001356337.1:p.Asn118= }\end{array}$ & & $0.498(\mathrm{~A})$ & Neutropenia & $4.6(1.2-17.4)$ & 3 & {$[48]$} \\
\hline & \multirow[t]{2}{*}{$E R C C 2$} & rs13181 & $\begin{array}{l}\text { NM_000400.3:c.2251A>C; } \\
\text { NP_000391.1:p.Lys751Gln }\end{array}$ & & $0.323(\mathrm{G})$ & Haematological & $2.2(1.3-3.8)$ & 3 & {$[62]$} \\
\hline & & rs238406 & $\begin{array}{l}\text { NM_000400.4:c.468A>C } \\
\text { NP_000391.1:p.Arg156= }\end{array}$ & & $0.645(\mathrm{C})$ & Thrombocytopenia & NA & NA & {$[63]$} \\
\hline & PARD3B & rs17626122 & $\begin{array}{c}\text { NM_001302769.2:c.3261-6168T>C } \\
\text { (Intronic) }\end{array}$ & & $0.550(\mathrm{~T})$ & Global toxicity & $3.4(1.9-6.8)$ & 3 & {$[57]$} \\
\hline & Intergenic & rs7325568 & Intergenic & & $0.409(\mathrm{~T})$ & Haematological & $1.8(1.3-2.4)$ & 3 & {$[57]$} \\
\hline
\end{tabular}


Table 3. Cont

\begin{tabular}{|c|c|c|c|c|c|c|c|c|c|}
\hline Drug & Gene & SNP (rsID) & Change & $\begin{array}{l}\text { Alternative } \\
\text { Nomenclature }\end{array}$ & $\begin{array}{l}\text { Frequency of } \\
\text { Risk Allele }^{\text {a }}\end{array}$ & Associated ADR & OR $(95 \%$ CI) & $\begin{array}{l}\text { Evidence } \\
\text { Level }^{b}\end{array}$ & Ref \\
\hline \multirow{13}{*}{ Irinotecan } & \multirow{5}{*}{ UGT1A1 } & rs3064744 & $\begin{array}{c}\text { NM_000463.3:c. } \\
\text { (Upstream transcript) }\end{array}$ & UGT1A1*28 & $\begin{array}{l}0.347 \text { (dupTA) } \\
\text { (EAS:0.122) }\end{array}$ & Global toxicity & $7.2(2.5-22.3)$ & $2 \mathrm{~A}$ & {$[64]$} \\
\hline & & rs4148323 c & $\begin{array}{l}\text { NM_000463.2:c.211G>A; } \\
\text { NP_000454.1:p.Gly71Arg }\end{array}$ & UGT1A1*6 & $\begin{array}{l}0.014 \text { (EAS: } \\
0.144)(\mathrm{A})\end{array}$ & NA & NA & $2 \mathrm{~A}$ & {$[65]$} \\
\hline & & rs11563250 & $\begin{array}{c}\text { NM_001367507.1:c. } \\
\text { (Genic upstream transcript) }\end{array}$ & & $0.893(\mathrm{~A})$ & Neutropenia & $0.3(0.2-0.6)$ & 3 & {$[66]$} \\
\hline & & rs4124874 & $\begin{array}{l}\text { NM_001072.3:c.862-10021T>G } \\
\text { (Intronic) }\end{array}$ & UGT1A1*60 & $0.452(\mathrm{~T})$ & Neutropenia & NA & 3 & {$[67]$} \\
\hline & & rs10929302 & $\begin{array}{c}\text { NM_019075.2:c.856-9898G>A } \\
\text { (Intronic) }\end{array}$ & UGT1A1*93 & $0.299(\mathrm{~A})$ & Global toxicity & $8.4(1.9-37.2)$ & 3 & {$[68]$} \\
\hline & \multirow{2}{*}{ UGT1A9 } & rs11692021 & $\begin{array}{l}\text { NM_021027.3:c. } 855+9770 \mathrm{~T}>\mathrm{C} \\
\text { (Intronic) }\end{array}$ & & $0.349(\mathrm{C})$ & Global toxicity & $2.0(1.1-3.6)$ & 3 & {$[69]$} \\
\hline & & rs3832043 e & $\begin{array}{c}\text { NM_021027.3:c. } \\
\text { (Upstream Transcript) }\end{array}$ & & $0.609(\mathrm{delT})$ & Diarrhoea & $6.3(1.3-31.7)$ & 3 & {$[70]$} \\
\hline & UGT1A6 & rs2070959 & $\begin{array}{c}\text { NM_001072.4:c.541A }>\mathrm{G} \\
\text { (Intronic) }\end{array}$ & & $0.689(\mathrm{~A})$ & Global toxicity & $2.1(1.1-3.9)$ & 3 & {$[69]$} \\
\hline & \multirow{2}{*}{$A B C G 1$} & rs225440 & $\begin{array}{l}\text { NM_016818.3:c.286+7029C }>\mathrm{T} \\
\text { (Intronic) }\end{array}$ & & $0.428(\mathrm{~T})$ & Neutropenia & $3.1(1.1-8.6)$ & 3 & {$[71]$} \\
\hline & & rs425215 & $\begin{array}{c}\text { NM_016818.3:c.974-898C >G } \\
\text { (Intronic) }\end{array}$ & & $0.623(\mathrm{G})$ & Gastrointestinal & $11.4(1.7-78.4)$ & NA & {$[72]$} \\
\hline & $A B C B 1$ & rs12720066 & $\begin{array}{c}\text { NM_001348945.1:c.2529+971T>G } \\
\text { (Intronic) }\end{array}$ & & $0.035(\mathrm{C})$ & Neutropenia & NA & 3 & {$[73]$} \\
\hline & \multirow{2}{*}{$A B C C 1$} & rs17501331 & $\begin{array}{l}\text { NM_004996.4:c.49-12232A>G } \\
\text { (Intronic) }\end{array}$ & & $0.928(\mathrm{~A})$ & Neutropenia & NA & 3 & {$[73]$} \\
\hline & & rs3743527 & $\begin{array}{c}\text { NM_004996.4:c.*543= } \\
\left(3^{\prime} \text { UTR }\right)\end{array}$ & & $0.774(\mathrm{C})$ & Neutropenia & NA & 3 & {$[73]$} \\
\hline
\end{tabular}


Table 3. Cont

\begin{tabular}{|c|c|c|c|c|c|c|c|c|c|}
\hline Drug & Gene & SNP (rsID) & Change & $\begin{array}{l}\text { Alternative } \\
\text { Nomenclature }\end{array}$ & $\begin{array}{l}\text { Frequency of } \\
\text { Risk Allele }^{\text {a }}\end{array}$ & Associated ADR & OR $(95 \% \mathrm{CI})$ & $\begin{array}{l}\text { Evidence } \\
\text { Level }^{b}\end{array}$ & Ref \\
\hline & \multirow{4}{*}{$A B C C 5$} & rs2292997 & $\begin{array}{l}\text { NM_005688.4:c.129+7980C }>\mathrm{T} \\
\text { (Intronic) }\end{array}$ & & $0.126(\mathrm{~A})$ & Neutropenia & $3.2(1.3-7.9)$ & 3 & {$[71]$} \\
\hline & & rs10937158 & $\begin{array}{l}\text { NM_005688.4:c.130-1268A>T } \\
\text { (Intronic) }\end{array}$ & & $0.612(\mathrm{C})$ & Diarrhoea & $0.4(0.2-0.8)$ & 3 & {$[71]$} \\
\hline & & rs3749438 & $\begin{array}{c}\text { NM_005688.4:c.591+374C>T } \\
\text { (Intronic) }\end{array}$ & & $0.324(\mathrm{~A})$ & Diarrhoea & $5.9(1.3-26.3)$ & 3 & {$[71]$} \\
\hline & & rs562 & $\begin{array}{c}\text { NM_005688.4:c. }{ }^{*} 1243= \\
\left(3^{\prime} \text { UTR }\right)\end{array}$ & & $0.515(\mathrm{C})$ & Gastrointestinal & $32.0(2.8-370.8$ & NA & {$[72]$} \\
\hline & $A B C G 2$ & rs7699188 & $\begin{array}{c}\text { NM_004827.3:c. } \\
\text { (Genic upstream transcript) }\end{array}$ & & $0.227(\mathrm{~A})$ & $\begin{array}{c}\text { Global toxicity; } \\
\text { non-haematological }\end{array}$ & $\begin{array}{l}7.3(1.5-34.5) \\
15.2(2.5-78.2)\end{array}$ & 3 & {$[74]$} \\
\hline & SLCO1B1 & rs2306283 & $\begin{array}{l}\text { NM_006446.5:c.388A>G } \\
\text { NP_006437.3:p.Asn130Asp }\end{array}$ & SLCO1B1*1b & $0.529(\mathrm{G})$ & Gastrointestinal & $2.3(0.4-15.1)$ & NA & {$[72]$} \\
\hline & TOP1 & rs6072262 & $\begin{array}{c}\text { NM_003286.4:c.279+61G }>A \\
\text { (Intronic) }\end{array}$ & & $0.144(\mathrm{~A})$ & Neutropenia & NA & 3 & {$[75]$} \\
\hline & TGFBR2 & rs3087465 & $\begin{array}{l}\text { NM_001024847.2:c. } \\
\text { (2KB upstream) }\end{array}$ & & $0.659(\mathrm{G})$ & Diarrhoea & $3.7(1.0-13.3)$ & 3 & {$[76]$} \\
\hline & TGFB1 & rs1800469 & $\begin{array}{c}\text { NM_000660.7:c. } \\
\text { (Upstream transcript) }\end{array}$ & & $0.701(\mathrm{G})$ & Diarrhoea & $4.4(1.0-18.9)$ & 3 & {$[76]$} \\
\hline & KCNQ5 & rs9351963 & $\begin{array}{c}\text { NM_019842.4:c.490-1798A>C } \\
\text { (Intronic) }\end{array}$ & & $0.178(\mathrm{C})$ & Diarrhoea & $3.3(1.8-5.6)$ & 3 & {$[77]$} \\
\hline & Intergenic & rs10486003 & Intergenic & & $0.913(\mathrm{C})$ & Neuropathy & $0.3(0.2-0.5)$ & NA & {$[78]$} \\
\hline & Intergenic & rs2338 & Intergenic & & $0.275(\mathrm{~A})$ & Neuropathy & $2.3(1.6-3.3)$ & NA & {$[78]$} \\
\hline & Intergenic & rs830884 & Intergenic & & $0.92(\mathrm{~T})$ & Neuropathy & $0.3(0.2-0.5)$ & $\mathrm{NA}$ & {$[78]$} \\
\hline & ACYP2 & rs 843748 & $\begin{array}{l}\text { NM_001320586.2:c.405-28913G >A } \\
\text { (Intronic) }\end{array}$ & & $0.379(\mathrm{~A})$ & Neuropathy & $2.4(1.6-3.7)$ & NA & {$[78]$} \\
\hline & DLEU7 & rs797519 & $\begin{array}{c}\text { NC_000013.11:g.50656996G>C } \\
\text { (Intronic) }\end{array}$ & & $0.548(\mathrm{G})$ & Neuropathy & $0.5(045-0.7)$ & NA & {$[78]$} \\
\hline & FARS2 & rs17140129 & $\begin{array}{c}\text { NM_001318872.2:c.-22+36771A>G } \\
\text { (Intronic) }\end{array}$ & & $0.158(\mathrm{G})$ & Neuropathy & $3.3(1.8-6.4)$ & NA & {$[78]$} \\
\hline
\end{tabular}


Table 3. Cont

\begin{tabular}{|c|c|c|c|c|c|c|c|c|c|}
\hline Drug & Gene & SNP (rsID) & Change & $\begin{array}{l}\text { Alternative } \\
\text { Nomenclature }\end{array}$ & $\begin{array}{l}\text { Frequency of } \\
\text { Risk Allele }^{\text {a }}\end{array}$ & Associated ADR & OR $(95 \%$ CI) & $\begin{array}{l}\text { Evidence } \\
\text { Level }^{b}\end{array}$ & Ref. \\
\hline \multirow{7}{*}{ Cetuximab } & \multirow{3}{*}{ EGFR } & rs712830 & $\begin{array}{c}\text { NM_005228.5:c.-191= } \\
\left(5^{\prime} \text { UTR }\right)\end{array}$ & & $0.894(\mathrm{C})$ & Global toxicity & $6.1(1.6-23.8)$ & 3 & [79] \\
\hline & & rs2227983 & $\begin{array}{l}\text { NM_005228.5:c.1562G>A } \\
\text { NP_005219.2:p.Arg521Lys }\end{array}$ & & $0.768(\mathrm{G})$ & Skin toxicity & $3.2(1.3-8.3)$ & 3 & [80] \\
\hline & & rs11568315 & $\begin{array}{c}\text { NM_005228.5:c.88+1195AC } \\
\text { [10] (Intronic) }\end{array}$ & & $\begin{array}{l}3.9 \times 10-4 \\
(\mathrm{CA}>35)\end{array}$ & Skin toxicity & $2.9(1.0-8.9)$ & NA & [81] \\
\hline & RPS7 & rs10203413 & $\begin{array}{c}\text { NC_000002.12:g.3581588G }>A \\
\text { (Regulatory region) }\end{array}$ & & $0.776(\mathrm{G})$ & Skin toxicity & $0.1(0.1-0.4)$ & NA & [82] \\
\hline & \multirow{2}{*}{ ZNF827 } & rs12646351 & $\begin{array}{c}\text { NC_000002.12:g.3581588G }>\mathrm{A} \\
\text { (Intronic) }\end{array}$ & & $0.815(\mathrm{G})$ & Skin toxicity & $0.04(0.01-0.3)$ & NA & [82] \\
\hline & & rs17806780 & $\begin{array}{l}\text { NM_001306215.2:c.2383+11920A>T } \\
\text { (Intronic) }\end{array}$ & & $0.818(\mathrm{~T})$ & Skin toxicity & $0.04(0.01-0.4)$ & NA & [82] \\
\hline & ЕРНА5 & rs7692430 & $\begin{array}{l}\text { NM_004439.8:c.2237-1876A>G } \\
\text { (Intronic) }\end{array}$ & & $0.156(\mathrm{G})$ & Skin toxicity & $4.6(2.5-8.5)$ & NA & [82] \\
\hline \multirow{4}{*}{ Bevacizumab } & \multirow{4}{*}{$V E G F$} & rs3025039 & $\begin{array}{c}\text { NM_001171623.1:c. }{ }^{* 237=} \\
\left(3^{\prime} \text { UTR }\right)\end{array}$ & & $0.134(\mathrm{~T})$ & Hypertension & $0.2(0.03-0.8)$ & NA & [83] \\
\hline & & rs2010963 & $\begin{array}{c}\text { NM_001171623.1:c.-634= } \\
\left(5^{\prime} \text { UTR }\right)\end{array}$ & & $0.698(G)$ & Hypertension & NA & NA & [84] \\
\hline & & rs833061 & $\begin{array}{l}\text { NM_001025366.3:c. } \\
\text { (Upstream transcript) }\end{array}$ & & $0.452(\mathrm{C})$ & Hypertension & $0.2(0.03-0.8)$ & NA & [85] \\
\hline & & rs699947 & $\begin{array}{l}\text { NM_001025366.3:c. } \\
\text { (Upstream transcript) }\end{array}$ & & $0.414(\mathrm{~A})$ & Hypertension & $0.1(0.01-0.6)$ & NA & [85] \\
\hline
\end{tabular}

a: The risk alleles frequencies were consulted on gnomAD. b: Measure of confidence in the association, according to PharmGKB [10]. c: Associated with changes in enzymatic activity, but with a particular adverse drug reaction (ADR). d: Described for tegafur, a prodrug of 5-FU. e: Described for non-small-cell lung carcinoma. NA: not available. Note: In case of multiple studies, we have chosen a publication used by PharmGKB to support the level of evidence of the referred variant, and the corresponding OR and $p$-value. 
A further meta-analysis including 7365 patients from eight different studies confirmed the association between DPYD rs55886062 (DDYD*13) and DPYD rs56038477 with gastrointestinal $(\mathrm{OR}=5.72, p=0.015 ; 2.04, p<0.0001$, respectively) and haematological toxicities (OR $=9.76, p=0.00014$; and 2.07, $p=0.013$, respectively), and also between DPYD rs3918290 and rs67376798 with overall toxicity (OR $=20.5, p<0.0001$; and 3.02, $p<0.0001$, respectively) [34].

\subsection{Thymidylate Synthetase (TYMS)}

TS, encoded by the TYMS gene, is the main target of fluoropyrimidines and low levels of expression may influence toxicity $[86,87]$. The two most studied SNPs in TYMS are rs2853542 (5'VNTR 2R/3R) and rs11280056 ( $3^{\prime}$ UTR $6 \mathrm{bp}$ ins-del). This gene has been widely studied, but with no conclusive results so far. Some studies have reported a correlation between rs2853542 and 5-FU/capecitabine toxicity, where the haplotype $2 \mathrm{R} / \mathrm{ins} 6$-bp was found to be significantly associated with severe toxicity $[45,87]$, but other works could not replicate this association [61]. This might be explained by a work of Rosmarin et al. in 2015, which reported an association of an intronic variant located in the overlapping ENOSF1 gene capable of explaining the toxicity attributed to the two previous TYMS polymorphisms. They discovered that SNP rs2612091 and TYMS 5'VNTR and 3'UTR are in moderate linkage disequilibrium (LD) $\left(\mathrm{r}^{2}=0.40\right.$ and 0.32 , respectively), but after testing for dependency, they concluded that it was the rs $2612091 \mathrm{G}$ allele alone that increased the risk of toxicity $(p=0.0021)$. Although it has been proposed that the ENOSF1 protein could influence TYMS activity, the interaction between these two genes is not yet well understood [41]. Interestingly, genetic variation in TYMS has also been related to response to pyrimidine treatments, with higher levels of TS implicating worse response and poorer overall survival $[88,89]$.

\subsection{Methylenetetrahydrofolate Reductase (MTHFR)}

MTHFR is the other major enzyme involved in 5-FU metabolism. Polymorphisms in this gene (namely rs1801133 and rs1801131) might impact enzyme activity, causing an accumulation of 5,10-MTHF, which increases toxicity [90]. Indeed, a study involving 292 stage II/III colon cancer patients found that the rs1801133 TT genotype was associated with neutropenia ( $\mathrm{OR}=2.32, p=0.014)$ [48]. Another study involving $118 \mathrm{mCRC}$ patients found that the same genotype was associated with diarrhoea $(p=0.02)$ [91]. However, other studies have not been able to find any association between polymorphisms in this gene and toxicity events $[61,62,92,93]$.

\subsection{Carboxyl Esterases (CES) and Cytidine Deaminase (CDA)}

CES2 is the first enzyme in the conversion of capecitabine to 5-FU, followed by a second step catalysed by CDA (Figure 1). There have been some attempts to prove the association of polymorphisms on these two genes with ADRs, but there are still no concrete positive results. Ribelles et al. studied 136 patients and showed a trend $(p=0.07)$ between HFS and CDA SNP rs3215400 [54]. A study including 239 patients found an association of $C D A$ rs2072671 with a high risk of overall toxicity $(\mathrm{OR}=1.84$, $p=0.029$ ) [53]. Another work including 430 patients linked the $C D A$ rs602950 and CDA rs532545 variants with diarrhoea ( $\mathrm{OR}=2.3, p=0.0055$, and 2.3, $p=0.0082$, respectively) [47]. There have also been some smaller studies on CES polymorphisms and their association with capecitabine toxicity $[45,54,94]$. CES proteins are also important in the catabolic pathway of irinotecan (Figure 3) [95]. CES1 rs2244613 was found to be associated with diarrhoea and patients with low CES2 expression are more prone to develop neutropenia or diarrhoea [95-98].

\subsection{DNA Repair Genes}

DNA repair pathways have been extensively studied in pharmacogenomic studies [99]. A metaanalysis of more than 1000 CRC patients receiving oxaliplatin found a single significant association of the ERCC1 rs11615 C allele with a higher risk of having haematological toxicity in Asian populations $(\mathrm{HR}=1.97, p<0.05)[100]$. Boige et al. could not, however, replicate this association, perhaps due 
to population differences, but did associate the ERCC2 rs13181 C allele with a higher risk of severe haematological toxicity caused by FOLFOX $(\mathrm{OR}=2.16, p=0.01)$ [62]. A recent study on $596 \mathrm{CRC}$ patients found that ERCC1 rs11615 was significantly associated with stomatitis ( $p=0.03$ ) and nausea $(p=0.04)$, and that ERCC2 rs13181 and rs238406 were associated with thrombocytopenia $(p=0.004$ and $p=0.03$, respectively) [63]. On the other hand, a study of 517 patients with stage II/III colon cancer concluded that polymorphisms in ERCC1 and XRCC1 did not have a clinically significant association with adverse effects [61]. Further smaller studies could neither confirm the relationship between these variants and toxicity $[91,101]$.

\subsection{Glutathione S-Transferases (GSTs)}

GST enzymes are proteins from a multigene family, and specifically, GSTP1, GSTM1 and GSTT1 are involved in oxaliplatin detoxification (Figure 2). The most studied variations are GSTP1 rs1695 and the complete deletion of the GSTT1 and GSTM1 genes. McLeod et al. tested these on 300 patients receiving FOLFOX in an advanced CRC setting. Patients bearing the GSTM1 null genotype had a 1.7-fold increased risk of having severe neutropenia $(p=0.016)$, whereas homozygous patients for the rs1695 $\mathrm{T}$ allele had higher probability of discontinuing FOLFOX treatment due to neurotoxicity $(p=0.01)$ [102]. In contrast to these findings, Boige et al. did not find any significant association between these same SNPs and severe neurotoxicity on a study enrolling 349 patients [62]. Ruzzo et al. studied 517 patients and suggested a weak association between the GST-T1/M1 null/null genotype and severe neutropenia ( $\mathrm{OR}=1.99, p=0.032)$ [61], whereas Cecchin et al. analysed 154 patients receiving FOLFOX but could not replicate any markers of neurotoxicity. Interestingly, they suggested that variants other than genetics, such as the biological state of patients or disease stage, may also influence the detoxification pathway, and could therefore be responsible for the FOLFOX-related neurotoxicity [58].

\subsection{Adenosine-Triphosphate Binding Cassette $(A B C)$ Transporters}

Genes within the ABC transporter family are responsible for the efflux of a variety of drugs and their metabolites, including oxaliplatin and irinotecan. However, there is a lot of controversy on the relationship of polymorphisms on $A B C$ genes and chemotherapy-related toxicity. For 206 patients receiving FOLFOX, Custodio et al. reported that the ABCG2 rs3114018 AA genotype had a significantly higher risk of neuropathy ( $\mathrm{OR}=2.67, p=0.059)$ [59]. In a study including 144 patients, Cecchin et al. reported positive associations with neurotoxicity for SNPs in $A B C C 2$ : $r 33740066$ (OR $=2.99, p=0.0231$ ), rs1885301 (OR = 3.06, $p=0.0072), \operatorname{rs} 4148396(\mathrm{OR}=4.69, p=0.0048)$ and $\mathrm{rs717620}(\mathrm{OR}=14.39$, $p=0.0164$ ), which are in high LD with one another. Others studies have been less successful in linking genetic variants in this gene with neurotoxicity or other toxicities [58,61,103].

In relation to irinotecan-based regimens, Salvador-Martín et al. showed that SNPs rs1128503, rs2032582 and rs1045642 in $A B C B 1$, which are in LD, were associated with haematological and overall toxicity [92]. Others proposed the association of solely $A B C B 1 \mathrm{rs} 1128503(\mathrm{OR}=2.02, p=0.401$ ) with global toxicity, or of $A B C B 1 \mathrm{rs} 1045642$ with early toxicity ( $\mathrm{OR}=3.79, p=0.098)$ (not strictly significant), while others did not find any association at all $[74,93,95,96]$. There have also been some reports on other $A B C$ transporter genes, with conflicting results. For instance, a study on $26 \mathrm{mCRC}$ patients showed that patients with the CC genotype in ABCC5 rs562 or the GG genotype in ABCG1 rs425215 presented higher gastrointestinal toxicity $(p<0.02)$ [72]. A study including 250 patients with mCRC linked the $A B C G 2$ rs7699188 variant with severe global toxicity (OR $=7.26, p=0.013)$ [74].

\subsection{Uridine Disphosphate Glucuronosyltransferases (UGTs)}

UGT1A1 is the main enzyme responsible for SN-38 inactivation, followed by UGT1A7 and UGT1A9. Several groups have studied the influence of UGT polymorphisms on toxicity development. One of the most studied polymorphisms in UGT1A1 is a change in the number of TA repeats (TA) ${ }_{n}$ TAA in the promoter region. The wild-type allele for this polymorphism is (TA) 6 TAA, with (TA) 7 TAA 
(rs3064744, UGT1A1*28) being frequent in Caucasians, but not in Asian populations $(\approx 30 \%$ and $\approx 10 \%$, respectively). However, rs4148323 (UGT1A1*6) is more frequent in Asian populations comparing with Caucasians $(\approx 14 \%$ and $\approx 1 \%$, respectively). Ando and colleagues reported that patients carrying the UGT1A1*28 genotype were at significantly higher risk of having irinotecan-related severe toxicity $(\mathrm{OR}=7.23, p<0.001)$ [64]. Innocenti et al. also stated that patients with UGT1A1*28 had more events of severe neutropenia ( $\mathrm{OR}=9.3, p=0.001)$ [67]. Others have also showed a correlation between UGT1A1*28 and neutropenia, diarrhoea and vomiting $(p<0.01)$ [104-107]. Additionally, as for TYMS, it has been proven that the UGT1A1 genotype also affects maximum tolerated dose and therefore response [108,109].

\subsection{Solute Carriers (SLCS)}

Reduction or elimination of the function of SLC genes due to genetic variation can lead to a decrease in SN-38 uptake, with further accumulation in plasma, ultimately leading to toxicity [97]. rs2306283 (SLCO1B1*1b) has been shown to cause severe gastrointestinal toxicity, particularly diarrhoea and neutropenia $[72,110,111]$. A discovery study on $167 \mathrm{mCRC}$ patients receiving irinotecan also revealed a protective effect of the SLCO1B1 rs2291076 T allele against neutropenia but associated the rs2306283 GG genotype with significantly higher neutropenia events. These results were, however, not replicated in a posterior study of $250 \mathrm{mCRC}$ patients [71].

\subsection{Cytochrome $p$ Gene Family (CYP)}

CYP3A4 and CYP3A5 are responsible for the oxidation of irinotecan into the inactive metabolites APC, M4 and NPC. Some researchers have studied the possible association of polymorphisms on these genes and chemo-related toxicity but have not found any positive correlation $[68,96,112]$, probably because over $80 \%$ of variants in CYP genes coding regions are very rare and the sample sizes of these studies were not large enough [113]. It has also been suggested that their enzymatic function might be altered by non-genetic factors such as diet, concomitant medications, altered liver function or patient's performance status [114].

\subsection{Epidermal Growth Factor Receptor (EGFR)}

Skin toxicity is the major ADR related to anti-EGFR agents. Parmar et al. studied 109 cancer patients and concluded that skin toxicity was linked to the EGFR rs2227983 GG genotype (OR $=3.24$, $p=0.014$ ) [80]. Dahan et al. studied 58 patients treated with third-line cetuximab and irinotecan, and reported a trend between the presence of $\operatorname{rs} 11568315$ (CA repeats $\leq 35)$ and skin toxicity $(\mathrm{OR}=2.91$, $p=0.058$ [ [81]. Sunakawa et al. studied 77 patients treated with cetuximab in combination with oxaliplatin and also correlated rs11568315 (CA repeats $\leq 19$ ) with skin toxicity [115]. A study on 52 patients treated with cetuximab and FOLFIRI found that $E G F R$ rs712830 was significantly associated with severe global toxicity ( $\mathrm{OR}=6.13, p=0.010)$, but not specifically with skin toxicity. rs712829, rs11568315 (CA repeats cut-off $=17$ ) and rs4444903 were, however, not associated with any toxicity [79]. Another study on $46 \mathrm{mCRC}$ patients receiving XELOX-bevacizumab with or without cetuximab also found no evidence for the association of either rs4444903 or rs11568315 (CA repeats cut-off $=20$ ) with skin toxicity [116].

\subsection{Vascular Endothelial Growth Factor (VEGF)}

Hypertension is the major toxicity derived from anti-VEGF agent treatment. Studies on the relationship of VEGF polymorphisms and bevacizumab-related toxicity have also been controversial. For instance, a study on 89 patients reported a positive link between rs3025039 and hypertension $(\mathrm{OR}=0.15, p=0.022)$, but a meta-analysis of over 1000 cancer patients did not validate this finding [83,117]. Moreover, some researchers have reported that patients with the rs833061 TT, rs2010963 CC or rs699947 CC genotypes were less prone to hypertension caused by bevacizumab 
$(p<0.03)[84,85]$, but Etienne-Grimaldi et al. saw that patients harbouring the rs2010963 CC genotype alone had more toxicity than patients with other genotypes $(p=0.01)$ [118].

\subsection{Immunotherapy and Toxicity}

Immunotherapy has arisen in the past few years as a promising therapeutic option in many cancers, and has particular relevance in the case of tumours with microsatellite instability (MSI) [119]. Hence, the FDA approved, in 2018, the use of ipilimumab and nivolumab (anti-CTLA-4 and anti-PD1 monoclonal antibodies, respectively) for the treatment of metastatic CRC patients previously treated with standard chemotherapy [120]. In 2020, pembrolizumab (anti-PD-1) was also approved as a first-line treatment of patients with unresectable, MSI-high or mismatch repair-deficient metastatic CRC [121]. Although there have been some studies suggesting the influence of genetic variants on the development of toxicity due to these treatments in other cancer types, to date there is no sufficient data on CRC [122-124]. Surely novel data on this will shortly become available for pharmacogenomic studies as more patients undergo immunotherapy treatment.

\section{Pharmacogenomic Approaches}

\subsection{Genome-Wide Association Studies (GWAS)}

Despite the large effect sizes for toxicity variants discovered by candidate gene approaches, chemotherapy-related toxicity is likely complex and multigenic. Therefore, other discovery strategies may be more suitable to inspect genomic variation in a more comprehensive manner. This has been made possible by the increasing availability of higher-throughput technologies at increasingly affordable prices, which has allowed pharmacogenetics to go genomic. In these upcoming sections, we will describe the more recent approaches that have further expanded the knowledge on pharmacogenomics in recent years (Table 4).

Table 4. Advantages and disadvantages of different pharmacogenomics approaches.

\begin{tabular}{|c|c|c|}
\hline Approach & Advantages & Disadvantages \\
\hline Candidate genes & $\begin{array}{l}\text { - } \quad \text { offers biological plausibility } \\
\text { associates variants with } \\
\text { known functional } \\
\text { consequences and direct } \\
\text { clinical implication }\end{array}$ & $\begin{array}{l}\text { bias toward certain genes/pathways } \\
\text { (usually, ADME genes) based on prior } \\
\text { information of relevance to phenotype, } \\
\text { which may be incomplete } \\
\text { - } \quad \text { unable to discover novel } \\
\text { genes/pathways } \\
\text { the selected SNPs may not represent } \\
\text { the full variation of the studied genes } \\
\text { - limited to protein-coding regions }\end{array}$ \\
\hline SNP arrays (GWAS) & $\begin{array}{l}\text { - } \quad \text { unbiased by a priori } \\
\text { functional knowledge } \\
\text { - } \quad \text { potential discovery of other } \\
\text { relevant genes/pathways } \\
\text { - } \quad \text { potential to identify variation } \\
\text { in regulatory regions such as } \\
\text { promoters or enhancers } \\
\text { high-throughput }\end{array}$ & $\begin{array}{l}\text { - } \\
\text { need to be adequately powered to } \\
\text { detect moderate-effect variants } \\
\text { - } \quad \text { require large sample sizes } \\
\text { multiple testing correction needs to } \\
\text { be applied } \\
\text { variants might be intergenic; } \\
\text { harder to interpret } \\
\text { inspects common populational } \\
\text { variation (potential loss of } \\
\text { rarer variants) } \\
\text { not suitable for CNV studies }\end{array}$ \\
\hline $\begin{array}{l}\text { SNP arrays (targeted } \\
\text { fine-mapping } \\
\text { approaches) }\end{array}$ & $\begin{array}{l}\text { - } \text { denser coverage } \\
\text { - } \quad \text { cheaper } \\
\text { - } \text { may be population-specific }\end{array}$ & $\begin{array}{l}\text { - } \quad \text { design bias } \\
\text { may require a priori knowledge of } \\
\text { region to study (i.e., as defined by } \\
\text { GWAS, for example). }\end{array}$ \\
\hline
\end{tabular}


Table 4. Cont.

\begin{tabular}{|c|c|c|}
\hline Approach & Advantages & Disadvantages \\
\hline $\begin{array}{l}\text { NGS (targeted panels, } \\
\text { WES, WGS) }\end{array}$ & $\begin{array}{l}\text { possibility of densely } \\
\text { resequencing an entire gene } \\
\text { (targeted genes) } \\
\text { allows a more comprehensive } \\
\text { and unbiased identification } \\
\text { of novel genetic biomarkers } \\
\text { allows the identification of } \\
\text { relevant rare variants } \\
\text { and CNV } \\
\text { rapid evolution of } \\
\text { NGS technologies }\end{array}$ & $\begin{array}{l}\text { - large number of false positives } \\
\text { and VUS } \\
\text { need for validation by Sanger or other } \\
\text { genotyping methods } \\
\text { higher turnaround time and costs } \\
\text { (although decreasing) } \\
\text { - need for high data storage capacity } \\
\text { need for deeper } \\
\text { bioinformatic knowledge }\end{array}$ \\
\hline Functional assays & 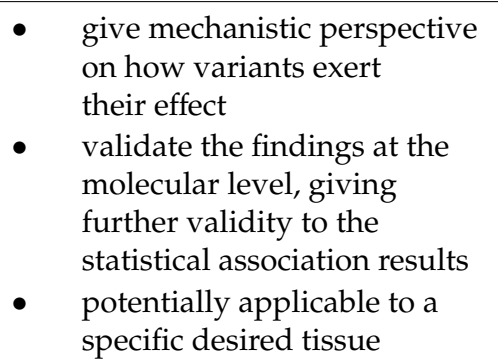 & $\begin{array}{l}\text { - assay design may be difficult, } \\
\text { particularly in the case of } \\
\text { intergenic variants } \\
\text { results must be replicated in } \\
\text { clinical studies }\end{array}$ \\
\hline
\end{tabular}

GWAS make use of LD inheritance patterns to inspect common genetic variation across the entire genome. The main two advantages of GWAS over candidate gene studies are that they are unbiased by a priori functional knowledge on the variants (which may help in the discovery of other toxicity relevant pathways) and also have the potential to identify variation in regulatory regions such as promoters or enhancers, which have been largely unexplored by candidate gene approaches.

Several GWAS have been performed to inspect chemotherapy-related toxicity in CRC. In the QUASAR2 trial, Rosmarin et al. analysed over 1000 stage II/III CRC patients receiving capecitabine with or without bevacizumab to identify 1456 variants on 25 candidate genes (Table 3) [41]. Fernandez-Rozadilla et al. used 1012 patients in a two-stage study in patients treated with 5-FU and FOLFOX [57] to find a moderate association for the rs10876844 variant and diarrhoea in patients treated with 5-FU. Won et al. also completed a GWAS on 343 Korean patients receiving oxaliplatin-based regimens to identify possible genetic markers associated with chronic oxaliplatin-induced peripheral neurotoxicity (OXCPN) [78]. They found some evidence for an association that was intronic or within $100 \mathrm{~Kb}$ of genes related to various neuronal activities. Two subsequent and independent studies by Oguri et al. and Terrazzino et al. tried to validate these findings, but a single association between the FARS2 rs17140129 G allele and OXCPN (OR $=6.5, p=0.034)$ was found $[125,126]$. Lastly, the CAIRO2 trial included 282 advanced or metastatic CRC individuals treated with XELOX plus bevacizumab and cetuximab. They found some novel SNPs to be moderately associated with toxicity (Table 3) [82].

In general, although GWAS present several advantages over candidate gene strategies, there are also some important limitations, some of which could be overcome post hoc. Firstly, there is a lack of replication due to discrepancies in variant frequencies amongst the different populations used between studies, as seen when comparing the works from Won et al. and Terrazzino et al. mentioned above (Asian vs. Caucasian populations, respectively). Further, most of the associated variants are intergenic, which makes it harder to interpret the results directly and design appropriate validatory functional assays. Moreover, because we are evaluating thousands to millions of variants at a time, statistical power is a concern, and adequate study sample sizes are needed [127]. As an illustration, for a GWAS with a sample size of 200 patients, assessing variants with minor allele frequency (MAF) $\geq 5 \%$, and a statistical threshold of $80 \%$ power, the OR that we would be able to discover is OR $\approx 2$, which reflects a moderate effect. 
GWAS are limited to inspecting common variation (i.e., generally over 5\% MAF), but it is likely that toxicity variants may be of rarer prevalence $[128,129]$. Some approaches have been developed to overcome this limitation. For instance, targeted SNP panels can be designed to fine-map regions of interest spanning a large section of the gene or specific to a desired population. As an example, a commercially available array has been designed to include both common and low-frequency variation as well as Mendelian and functional alleles specific to Spanish genomes, which allows for better genotyping of the Spanish population when comparing with the generic global arrays [130]. Moreover, albeit possible, GWAS strategies are not usually suitable for CNV studies, because they demand that the CNV be in high LD with a genotyped SNP [57].

Despite these limitations, GWAS still hold great potential for discovery, given appropriate study conditions. Surely, there are still pathways contributing to toxicity development to be discovered, as proven by the contribution of RPS7 to cetuximab-related toxicity. This gene is normally overexpressed in dermal papilla cells, which makes it reasonable that genetic variants could be associated with skin toxicity [82].

\subsection{Next-Generation Sequencing (NGS)}

NGS, either whole-exome (WES) or whole-genome sequencing (WGS), allows for a more comprehensive identification of novel genetic biomarkers in this regard, and several studies have reported the added value of NGS to identify relevant rare pharmacogenetic variants that would not be detected by other conventional methods (Table 4) [131-136].

In 2014, Mizzi et al. compared the data from 482 healthy individuals (data from Genomes Data and the Wellderly Study) obtained either with WGS or SNP array genotyping that included 1936 known pharmacogenomic variants within 231 ADMET genes (Table 5) [131]. Focusing on these genes, the WGS revealed an average of 17,733 variants vs. 249.5 found with the SNP array. In silico analysis with the PROVEAN and SIFT algorithms, which are in silico functional predictors, showed some missense variants likely to be deleterious. Specifically, they found that 254 of the 332 variants in UGT1A1 were novel, of which 31 were functional and 26 had a frequency of $<1 \%$. In general, the WGS approach allowed the identification of a significantly higher number of variants compared to the SNP array, which might impact the pharmacological processes.

Table 5. Summary of relevant next-generation sequencing (NGS) results.

\begin{tabular}{|c|c|c|c|c|c|}
\hline $\mathbf{N}$ & Cohort & Method & Genes & Results & Ref. \\
\hline 482 & $\begin{array}{l}\text { Genomes Data, } \\
\text { Wellderly Study }\end{array}$ & $\begin{array}{l}\text { WGS or SNP } \\
\text { array } \\
\text { genotyping }\end{array}$ & $\begin{array}{c}231 \\
\text { pharmacogenes }\end{array}$ & $\begin{array}{l}\approx 17,733 \text { (WGS) vs. } 249.5 \text { (SNP array) } \\
\text { UGT1A1 (WGS): } 254 \text { of } 332 \text { variants } \\
\text { were novel, } 31 \text { functional and } 26 \text { with } \\
\text { frequency }<1 \% .\end{array}$ & [131] \\
\hline$>6500$ & 1KG phase 3; ESP & WES and WGS & $\begin{array}{c}146 \\
\text { pharmacogenes }\end{array}$ & $\begin{array}{c}19,328 \text { SNV, } 62.9 \% \text { exonic } \\
6225 \text { and } 6258 \text { variants in } A B C \\
\text { transporter (22 genes) and SLC genes } \\
\text { (49), respectively, } 253 \text { variants in } \\
\text { UGTs }(16) \text { and GTSs }(14) \\
92.9 \% \text { rare, } 82.7 \% \text { very rare } \\
56.2 \% \text { missenses } \\
\approx 30-40 \% \text { of the functional variability } \\
\text { in pharmacogenes }\end{array}$ & [133] \\
\hline 141,456 & gnomAD v $2.1^{\mathrm{a}}$ & WES and WGS & SLC genes & $\begin{array}{c}204,287 \text { SNVs and indels, } \\
56.9 \% \text { missenses, } 2.5 \% \text { frameshifts, } \\
1.7 \% \text { stop-gains and } 1.5 \% \text { variations } \\
\text { in canonical splice sites } \\
\text { Each individual had } \approx 29.7 \text { putatively } \\
\text { functional } S L C \text { variants, } 18 \% \text { of } \\
\text { functional variability due to } \\
\text { rare variants }\end{array}$ & [136] \\
\hline
\end{tabular}


Table 5. Cont.

\begin{tabular}{|c|c|c|c|c|c|}
\hline $\mathbf{N}$ & Cohort & Method & Genes & Results & Ref. \\
\hline 100 & QUASAR & $\begin{array}{c}\text { Amplicon } \\
\text { sequencing }\end{array}$ & $\begin{array}{l}D P Y D \text { and } \\
\text { TYMS coding } \\
\text { regions }\end{array}$ & $\begin{array}{c}\text { Novel rare independent DPYD } \\
\text { variant (c.1651G }>\text { A; } \\
\text { p.Ala551Thr)—classified as } \\
\text { strongly damaging }\end{array}$ & [41] \\
\hline 62,402 & $\begin{array}{c}1 \mathrm{KG}_{\text {phase }} \text {; } \\
\text { ExAC }^{\mathrm{b}}\end{array}$ & WES and WGS & $\begin{array}{c}208 \\
\text { pharmacogenes }\end{array}$ & $\begin{array}{c}201(97 \%) \text { genes had } 5589 \text { novel CNVs, } \\
47 \% \text { deletions and } 54 \% \text { duplications } \\
\text { Novel deletions responsible for }>5 \% \\
\text { of loss-of-function alleles in } 87,25,49, \\
48,59 \text { and } 51 \text { genes in non-Finnish } \\
\text { Europeans, Finnish, East Asians, } \\
\text { South Asians, Africans and admixed } \\
\text { Americans, respectively }\end{array}$ & [134] \\
\hline
\end{tabular}

1 KG: 1000 Genomes Project; ESP: Exome Sequencing Project; a: non-Finnish Europeans, Finns, Africans, East Asians, South Asians, Latinos, Ashkenazi Jews and other populations; ExAC: Exome Aggregation Consortium; b: included six major populations: non-Finnish Europeans, Finns, Africans, South Asians, East Asians and admixed Americans.

Another study analysed sequencing data for 146 genes related to pharmacological traits from over 6500 individuals (data from the 1000 Genomes Project (1KGP) and Exome Sequencing Project (ESP)) (Table 5) [133]. They detected 19,328 single nucleotide variants (SNVs), 62.9\% of which were exonic; for example, 6225 and 6258 variants in $A B C$ transporter (22 genes) and SLC genes (49) respectively, and 253 variants in UGTs (16) and GTSs (14). Most of these variants were indeed rare (MAF < $1 \%$; $92.9 \%$ ) or very rare (MAF $<0.1 \% ; 82.7 \%$ ) - meaning that they would not be detected by conventional methods-and the majority were missenses $(56.2 \%)$. The functional impact from rare variants was different across the genes, yet they concluded that rare variants contribute on average $30-40 \%$ of the functional variability in the studied pharmacogenes.

Schaller et al. analysed WES and WGS data from 141,456 individuals (data from gnomAD v2.1) and assessed the genetic variability of SLC genes (Table 5) [136]. They detected 204,287 SNVs and indels, of which $56.9 \%$ were missenses, and several were loss-of-function variants, such as $2.5 \%$ frameshifts, $1.7 \%$ stop-gains and $1.5 \%$ variations in canonical splice sites. They concluded that each individual presents, on average, 29.7 putatively functional SLC variants, with rare variants contributing $18 \%$ of this functional variability.

Following on from the results obtained from their initial GWAS, Rosmarin et al. sequenced the complete DPYD and TYMS coding regions and identified a further novel rare independent DPYD variant (c.1651G>A; p.Ala551Thr). This change was present in a single patient that had presented with grade 4 neutropenia and thrombocytopenia, and was predicted to be "strongly damaging" by in silico predictors (Table 4) [41].

NGS approaches can not only be useful to identify rarer variants but can be an important asset to reveal copy number variations (CNVs). The case in point is the work by Santos et al. that included CNV available data from 2504 whole genomes and 59,898 exomes (data from 1KGP and Exome Aggregation Consortium (ExAC)) and focused on 208 ADME genes (Table 5) [134]. Within these, 201 (97\%) genes had a total of 5589 novel CNVs, where $47 \%$ were deletions and $54 \%$ were duplications. These novel deletions were responsible for $>5 \%$ of loss-of-function alleles in a considerable number of genes $(87,25$, 49, 48, 59 and 51 genes in non-Finnish Europeans, Finnish, East Asians, South Asians, Africans and admixed Americans, respectively). This demonstrates the impact that CNV might have on ADME genes, and hence the development of ADRs.

As the conventional screening methods only include common variants, a high number of variants are missed, thus explaining the need for unbiased and more comprehensive approaches. These interesting works emphasise the potential of NGS to detect novel rarer variants or CNV, not only in ADME genes, but in other pathways, which might help to explain the pharmacogenetic variability possibly associated with toxicity caused by chemotherapy. 


\section{Functional Assays}

Functional assays on candidate variants are essential to ultimately clarify the mechanisms by which the genetic variants exert their effect on ADR development. Pharmacokinetic (PK) studies have been the most used approach to assess the functional impact of toxicity SNPs (Table 4). They have been used for many years now to evaluate enzymatic activity in patients carrying the desired variants, as they measure the level of drug and its metabolites that influence drug bioavailability and could hence lead to the toxicity profile.

By far, the most studied gene in PK studies has been DPYD, and there is an agreement that the DPD protein plays a crucial role in 5-FU metabolism. There are several methods to determine DPD deficiency [30,137]: testing for DPD activity in peripheral blood mononuclear cells, the uracil breath test, the uracil test dose and endogenous DHU/U ratio, or high-performance liquid chromatography (HPLC).

A study including 30 patients heterozygous for the DPYD rs3918290 variant analysed 5-FU plasma concentrations by HPLC and found that the mean maximum enzymatic 5-FU conversion capacity value was $40 \%$ lower in these patients (Table 6) [138].

Table 6. Pharmacokinetic studies on fluoropyrimidines and irinotecan.

\begin{tabular}{|c|c|c|c|c|}
\hline Genes & $\begin{array}{l}\text { Significant } \\
\text { Variants }\end{array}$ & $\mathbf{N}$ & Pharmacokinetic Results & Ref. \\
\hline \multicolumn{5}{|c|}{ Fluoropyrimidines } \\
\hline$D P Y D$ & rs3918290 & $\begin{array}{l}1 \text { case (heterozygous } \\
\text { for IVS14+1G>A) vs. } \\
6 \text { controls }(\mathrm{CRC})\end{array}$ & $\begin{array}{l}\text { inactivation of one } D P Y D \text { allele: strong } \downarrow C L_{5-\mathrm{FU}} \text { : } \\
\text { severe toxicity }\end{array}$ & [139] \\
\hline$D P Y D$ & $\begin{array}{l}\text { rs1801265 } \\
\text { rs115232898 } \\
\text { rs55886062 }\end{array}$ & 175 CRC patients & $\begin{array}{l}\text { rs55886062: lowest activity }(p=0.014) \\
\text { rs115232898: } 46 \% \downarrow \text { activity }(p=0.026) \\
\text { rs1801265: } 27 \% \text { activity }(p=0.013)\end{array}$ & [140] \\
\hline$D P Y D$ & $\begin{array}{l}\text { rs3918290 } \\
\text { rs67376798 } \\
\text { rs55886062 }\end{array}$ & $\begin{array}{l}487 \text { advanced } \\
\text { carcinoma patients }\end{array}$ & $\begin{array}{c}\text { rs3918290, rs67376798, or rs55886062: } \downarrow \mathrm{CL}_{5-\mathrm{FU}} \\
(p<0.001)\end{array}$ & [141] \\
\hline$D P Y D$ & rs3918290 & $\begin{array}{c}30 \text { patients } \\
\text { (heterozygous for } \\
\text { IVS14+1G }>\text { A) and } \\
18 \text { controls }\end{array}$ & rs3918290: $40 \% \downarrow V \max (p<0.001)$ & [142] \\
\hline$D P Y D$ & rs1801159 & $\begin{array}{l}112 \text { gastric or colon } \\
\text { cancer patients }\end{array}$ & $\begin{array}{c}\text { rs1801159: } \downarrow \mathrm{k}(p=0.022) \text { and nausea/vomiting } \\
(p=0.005)\end{array}$ & [143] \\
\hline$D P Y D$ & $\begin{array}{l}\text { rs55886062 } \\
\text { rs1801265 } \\
\text { rs1801158 }\end{array}$ & Expression vector & $\begin{array}{l}\text { rs1801158: } 36 \% \uparrow \text { activity }\left(p=3.4 \times 10^{-7}\right) \\
\text { rs1801265: } 13 \% \uparrow \text { activity }(p=0.0013) \\
\text { rs55886062: } 75 \% \downarrow \text { activity }\left(p=5.2 \times 10^{-9}\right)\end{array}$ & [29] \\
\hline$D P Y D$ & $\begin{array}{c}\text { rs141044036 } \\
\text { rs72549308 } \\
\text { rs1801268 } \\
\text { rs145773863 } \\
\text { rs55674432 } \\
\text { rs72547601 } \\
\text { rs137999090 } \\
\text { rs59086055 } \\
\text { rs1801266 } \\
\text { rs111858276 } \\
\text { rs183385770 } \\
\text { rs72549307 } \\
\text { rs138616379 } \\
\text { rs72549304 } \\
\text { rs112766203 } \\
\text { rs183105782 } \\
\text { rs143986398 } \\
\text { rs115232898 } \\
\text { rs2297595 }\end{array}$ & Expression vector & $\begin{array}{c}\text { rs141044036, rs72549308, rs1801268, rs145773863, } \\
\text { rs55674432, rs137999090, rs72547601, rs59086055: } \\
<12.5 \% \text { activity }\left(p<3.5 \times 10^{-4}\right) \\
\text { rs1801266, rs72549307, rs111858276, rs138616379, } \\
\text { rs183385770, rs72549304: } 12.5-25 \% \text { activity }(p<0.0021) \\
\text { rs112766203, rs143986398, rs183105782, rs115232898: } \\
>25 \% \downarrow \text { activity }(p<0.05) \\
\text { rs2297595: } 120 \% \uparrow \text { activity }(p=0.025)\end{array}$ & [31] \\
\hline$A B C$ & rs2271862 & 48 CRC patients & $A B C A 2$ rs2271862: $\uparrow C L_{5-F U}$ & [144] \\
\hline
\end{tabular}


Table 6. Cont.

\begin{tabular}{|c|c|c|c|c|}
\hline Genes & $\begin{array}{l}\text { Significant } \\
\text { Variants }\end{array}$ & $\mathbf{N}$ & Pharmacokinetic Results & Ref. \\
\hline $\begin{array}{l}A B C B 1 \\
A B C C 1 \\
A B C G 2 \\
\text { UGT1A1 }\end{array}$ & $\begin{array}{l}\text { rs12720066 } \\
\text { rs6498588 } \\
\text { rs10929302 }\end{array}$ & $\begin{array}{l}85 \text { advanced cancer } \\
\text { patients }\end{array}$ & $\begin{array}{c}A B C B 1 \mathrm{rs} 12720066\left(p=6.24 \times 10^{-4}\right) \text { and } \mathrm{rs} 6498588 \\
\left(p=9.50 \times 10^{-4}\right), \text { and } U G T 1 A 1 \mathrm{rs} 10929302 \\
\left(p=9.00 \times 10^{-5}\right): \uparrow A U C_{\mathrm{SN}-38} \\
\uparrow \mathrm{AUC}_{\mathrm{SN}-38}: \mathrm{G} \geq 3 \text { neutropenia }(p=0.0001)\end{array}$ & [73] \\
\hline $\begin{array}{l}\text { ABCG2 } \\
\text { SLCO1B1 } \\
\text { ABCB1 } \\
\text { ABCC1 } \\
\text { ABCC2 } \\
\text { UGT1A1 } \\
\text { UGT1A9 } \\
\text { UGT1A7 } \\
\text { CES } \\
\text { CYP3A4 } \\
\text { CYP3A5 } \\
\text { HNF1A }\end{array}$ & $\begin{array}{c}\text { rs717620 } \\
\text { rs1169288 } \\
\text { rs4149056 } \\
\text { rs35605 } \\
\text { rs1092302 } \\
\text { rs3740066 }\end{array}$ & $\begin{array}{l}85 \text { advanced cancer } \\
\text { patients }\end{array}$ & 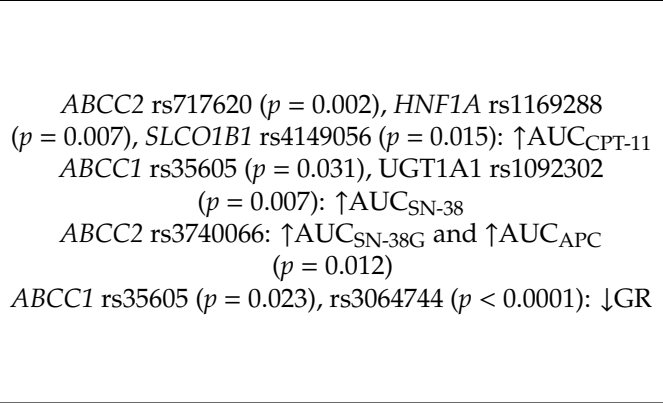 & [111] \\
\hline UGT1A1 & rs3064744 & $250 \mathrm{mCRC}$ patients & $\begin{array}{l}\downarrow \mathrm{GR}(p=0.01) \text { and } \uparrow \mathrm{BI}(p=0.003): \mathrm{G} \geq 3 \text { toxicity } \\
\text { rs3064744: } \downarrow \mathrm{GR}(p=0.01) \text { and } \uparrow \mathrm{BI}(p=0.007)\end{array}$ & [145] \\
\hline $\begin{array}{l}\text { UGT1A1 } \\
\text { UGT1A7 } \\
\text { UGT1A9 }\end{array}$ & $\begin{array}{l}\text { rs4124874 } \\
\text { rs10929302 } \\
\text { UGT1A7*3 }\end{array}$ & Subset of 71 patients & $\begin{array}{c}\text { UGT1A1 rs4124874 and rs10929302: } \uparrow \mathrm{BI}(p=0.03 \text { and } \\
p=0.04 \text {, respectively) } \\
\qquad \begin{array}{l}\text { UGT1A7*3: } \downarrow \text { GR }(p=0.02) \text { and } \uparrow \mathrm{BI}(p=0.007)\end{array}\end{array}$ & [146] \\
\hline HNF1A & rs2244608 & Subset of 49 patients & $\begin{array}{c}\text { rs2244608: } \uparrow \mathrm{AUC}_{\mathrm{SN}-38}(p=0.032), \uparrow \mathrm{BI}(p=0.021) \text { and } \\
\downarrow \downarrow \mathrm{GR}(p=0.035)\end{array}$ & [147] \\
\hline$A B C C 2$ & $\begin{array}{c}\text { rs2273697 } \\
\text { rs17216114 } \\
\text { rs1885301 } \\
\text { rs2804402 } \\
\text { rs717620 } \\
\text { rs3740066 }\end{array}$ & $31 \mathrm{mCRC}$ patients & $\begin{array}{c}\text { rs2273697: } \downarrow \text { AUUC } C_{\mathrm{CPT}-11}(p=0.011) \\
\text { rs17216114: } \downarrow \text { AUUC } C_{\mathrm{SN}-38} \\
\text { rs1885301, rs2804402, rs717620 and rs3740066: } \\
\uparrow \mathrm{AUN}_{\mathrm{SN}-38}(p<0.03)\end{array}$ & [148] \\
\hline $\begin{array}{l}A B C B 1 \\
A B C C 1 \\
A B C C 2 \\
A B C G 2 \\
C E S 1 \\
\text { CES2 } \\
\text { CYP3A4 } \\
\text { CYP3A5 } \\
\text { UGT1A } \\
\text { XRCC1 }\end{array}$ & rs1128503 & $\begin{array}{l}65 \text { solid tumour } \\
\text { patients }\end{array}$ & $\begin{array}{c}A B C B 1 \mathrm{rs} 1128503: \uparrow \mathrm{AUC}_{\mathrm{CPT}-11}(p=0.038), \mathrm{AUC}_{\mathrm{SN}-38} \\
(p=0.031) \text { and } \downarrow \mathrm{CL}_{\mathrm{SN}-38}(p=0.015)\end{array}$ & [96] \\
\hline UGT1A1 & rs3064744 & $\begin{array}{l}20 \text { solid tumour } \\
\text { patients }\end{array}$ & $\begin{array}{l}\text { rs3064744 } \downarrow G R(p=0.001) \text { and } \uparrow \mathrm{BI}(p=0.001) \\
\text { AUC }_{\mathrm{SN}-38} \text { : neutropenia }(p<0.0001)\end{array}$ & [105] \\
\hline $\begin{array}{l}\text { UGT1A1 } \\
\text { UGT1A9 }\end{array}$ & rs3064744 & $\begin{array}{l}94 \text { solid tumour } \\
\text { patients }\end{array}$ & rs3064744: $\downarrow$ GR $(p=0.022)$ & [149] \\
\hline UGT1A1 & $\begin{array}{l}\text { rs } 4148323 \\
\text { rs4124874 } \\
\text { rs3064744 }\end{array}$ & $\begin{array}{l}85 \text { solid tumour } \\
\text { patients }\end{array}$ & $\begin{array}{l}\text { rs4148323: } \downarrow \mathrm{GR}(p=0.0372) \\
\text { rs4124874: } \uparrow \mathrm{BI}(p=0.0048) \\
\mathrm{rs3064744:} \uparrow \mathrm{BI}(p=0.0007)\end{array}$ & [150] \\
\hline $\begin{array}{l}A B C C 2 \\
\text { UGT1A1 }\end{array}$ & $\begin{array}{l}A B C C 2 * 2 \\
\text { rs306474 }\end{array}$ & $\begin{array}{l}167 \text { solid tumour } \\
\text { patients }\end{array}$ & $\begin{array}{c}A B C C 2 * 2: \downarrow \mathrm{CL}_{\mathrm{CPT}-11}(p=0.020) \\
\text { rs3064744: } \downarrow \mathrm{CL}_{\mathrm{SN}-38}(p<0.001), \mathrm{GR} \text { and } \mathrm{BI}(p=0.014)\end{array}$ & [151] \\
\hline UGT1A1 & rs3064744 & $\begin{array}{l}62 \text { solid tumour } \\
\text { patients }\end{array}$ & $\begin{array}{c}\text { rs3064744: } \downarrow \mathrm{CL}_{\mathrm{SN}-38}(p<0.01) \\
\uparrow \mathrm{SN}-38 \text { exposure: } \mathrm{G} 2-3 \text { diarrhoea }(p=0.03)\end{array}$ & [152] \\
\hline UGT1A1 & rs3064744 & $\begin{array}{l}65 \text { solid tumour or } \\
\text { lymphoma patients }\end{array}$ & $\begin{array}{c}\text { rs3064744: } \uparrow \text { BI }(p=0.0003) \text { and } \downarrow \text { GR }(p=0.03) \\
\uparrow \text { BI: G4 neutropenia }(p=0.001)\end{array}$ & [67] \\
\hline $\begin{array}{l}\text { UGT1A1 } \\
\text { UGT1A7 } \\
\text { UGT1A9 } \\
\text { UGT1A10 }\end{array}$ & $\begin{array}{l}\text { rs3064744 } \\
\text { rs4148323 }\end{array}$ & 176 cancer patients & rs3064744 or rs4148323: $\downarrow$ GR $(p<0.0001)$ & [153] \\
\hline $\begin{array}{l}\text { UGT1A1 } \\
\text { ABCG2 }\end{array}$ & rs4148323 & 45 cancer patients & $\begin{array}{c}\text { rs4148323: } \uparrow \mathrm{AUC}_{\mathrm{SN}-38}(p=0.018), \downarrow \mathrm{GR}(p=0.006) \text { and } \\
61 \% \uparrow \mathrm{BI}(p=0.003)\end{array}$ & [154] \\
\hline$A B C B 1$ & $A B C B 1^{*} 2$ & 49 cancer patients & 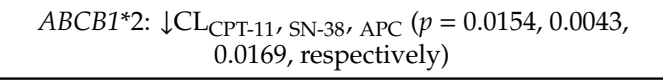 & [155] \\
\hline
\end{tabular}

Enzymatic activities were measured by high performance liquid chromatography (HPLC). 
Another study reported the effect of DPYD rs75017182 on DPD expression and activity and showed that heterozygous carriers presented a $35 \%$ activity reduction that was caused by alternative splicing [33].

By these means, at least four SNPs in DPYD have been proven deleterious: rs55886062, rs3918290, rs67376798 and rs56038477/HapB3 [30,34,156]. Studies on other variations have so far led to inconclusive or contradicting results [157].

Of late, other approaches have also been used to assess the functionality of pharmacogenetic variants. For instance, Offer et al. proposed the construction of a vector for rapid phenotypic assessment of DPYD variants and their relation with 5-FU sensitivity (Table 6) [29,31]. DPYD constructs were expressed in mammalian cells and the enzymatic activity of the expressed proteins was measured by HPLC and compared to the wild type. By these means, they could confirm that 30 of the variants caused a significant reduction in enzymatic activity. Interestingly, 19 of the variants tested displayed $<25 \%$ activity. In turn, DPYD rs1801158, rs1801265, rs2297595, rs200687447, rs60139309 and rs114096998 had higher enzymatic activity, and therefore cells expressing these variants were more resistant to 5-FU, which may not confer susceptibility to toxicity development, but may in turn influence response rates.

In 2015, Henricks et al. proposed to assign an activity value (AV) to DPYD alleles, to adjust the initial dose of 5-FU. In this context, fully functional alleles had an $A V=1$, reduced activity alleles had an $\mathrm{AV}=0.5$ and non-functional alleles had an $\mathrm{AV}=0$ (wild-type $\mathrm{AV}=1$; rs67376798 and rs56038477 $\mathrm{AV}=0.5$; and rs3918290 and rs55886062 AV =0). Based on the AV of both alleles, the gene activity score (AS) is calculated, thus representing the enzymatic phenotype of the patient [30].

For genes other than $D P Y D$, there is much less functional evidence (Table 6). Some research has been conducted on the relation of irinotecan PK variants. These studies were able to significantly associate polymorphisms in $A B C C 1$ and $A B C B 1$ with $\mathrm{SN}-38$ exposure and the glucuronidation ratio (GR) - measured as AUC SN-38G/AUC SN-38 [73,111]. Demattia et al. investigated the possible association between $A B C G 2$ rs7699188 and $A B C B 1$ rs2032582 with irinotecan PK parameters on patients with advanced CRC by measuring plasma concentrations of irinotecan, SN38 and SN38G, but did not find any significant correlation [74]. Toffoli et al. evaluated irinotecan PK in 71 patients with metastatic CRC. They associated severe toxicity with a significantly lower GR $(p=0.01)$ and an increased biliary index (BI) $(p=0.003)$, which indicates SN-38 accumulation. Further, they reported a significant correlation between UGT1A1*28 and lower GR $(p=0.01)$, and higher BI $(p=0.007)$ [145]. Other works showed that patients with the wild-type genotype had a significantly higher clearance of SN-38 compared to UGT1A1*28 $(p<0.001)$, and that the homozygous genotype was significantly associated with GR $(p=0.005)$ and BI $(p=0.014)$ [151]. Iyer et al. also reported significantly lower SN-38 glucuronidation in patients with $U G T 1 A 1^{*} 28(p=0.001)$ [105]. Other UGT1A polymorphisms, such as UGT1A1*60 ( $p=0.005)$, UGT1A1*93 $(p<0.0001)$, UGT1A1*6 $(p=0.037)$ and UGT1A7*3 $(p<0.02)$, were also associated with GR and BI $[73,146,150]$.

\section{Cost-Effectiveness Analysis}

Besides the need for clear evidence on the functional relevance of a pharmacogenetic biomarker, a proof of cost-effectiveness-that the pharmacogenetic strategy is more effective with an acceptable additional cost or even a cost saving - is crucial to facilitate its introduction into clinical practice and acceptance from healthcare professionals and institutions.

In 2015, Deenen et al. evaluated the safety and costs of upfront DPYD*2A genotyping with individualised dose adjustment treatment for fluoropyrimidines [158]. They showed that genotypeguided dosing represented a reduction in severe toxicity from $73 \%$ to $28 \%$. Moreover, dose adjustment based on genotype produced shorter and easier to control toxicities, and a significant reduction in drug-induced death from $10 \%$ to $0 \%$. Therefore, they demonstrated that screening for DPYD*2A before treatment could be lifesaving and potentially cost-efficient. Cortejoso et al. complementarily evaluated the costs of genotyping three DPYD variants (rs3918290, rs67376798 and rs55886062) and the management of severe neutropenia caused by fluoropyrimidines. Considering an average cost 
of management of EUR 3044.40 vs. EUR 6.40 per patient for DPYD testing, they concluded that genotyping is cost-effective if severe neutropenia is prevented in at least 2.1 cases per 1000 treated patients [159]. Given that the combined frequency of these three markers is about $1 \%$, this provides evidence that DPYD testing should be considered by healthcare systems. Murphy et al. further compared the reactive vs. prospective DPYD genotyping of variants rs3918290, rs67376798, rs 1801158 and rs55886062. Of the 134 included patients, five carried a DPYD variant and the costs of their hospitalisation were EUR 232,061, whereas the total cost of genotyping prior to treatment for all patients would have been only EUR 23,718. Even if patients still had to endure some ADRs, the cost would have been considerably smaller, making pharmacogenetic analysis again cost-efficient [160]. In 2019, Henricks et al. also compared the costs from prospective DPYD screening (rs3918290, rs67376798, rs55886062 and rs56038477) with no screening on 1103 patients receiving fluoropyrimidine-based therapy. Patients with variants rs 67376798 or rs 56038477 had a $25 \%$ dose reduction, while patients with rs3918290 or rs55886062 had a 50\% dose reduction. They concluded that the expected costs of the screening approach were EUR 2599 vs. EUR 2650 for the non-screening approach, representing a cost saving of EUR 51 per patient. These results strongly suggested that upfront DPYD-guided dose individualisation does not result in extra costs, and therefore solidly supports DPYD screening implementation prior to fluoropyrimidine treatment as a standard of care [161]. It also constituted the basis for pharmGKB EMA guideline changes from actionable to recommended.

Gold et al. assessed the safety and costs of testing for UGT1A1*28 before irinotecan treatment [162]. Assuming no treatment efficacy reduction, the average cost saving per patient was EUR 250. Obradovic et al. compared the standard irinotecan dose with dose reduction based on UGT1A1 genotyping, and evaluated the cases of severe neutropenia, the number of life-years gained and the associated costs. They concluded that genotyping with dose reduction in homozygotes was cost-saving in African and Caucasian populations, but not in Asians, given the population frequency of this variant [163]. Another study by Butzke et al. compared severe neutropenia and grade 4 diarrhoea in a similar setting, to find that dosage calculations based on UGT1A1*28 genotypes save about EUR 600 per patient [164]. More recently, Roncato et al. calculated that the costs for toxicity management per patient increased 1.4-fold for heterozygotes and 6-fold for homozygotes compared to wild-type individuals, and they were superior to the costs related to genotyping all patients before treatment [165].

\section{Pharmacogenomic Testing Guidelines}

Although, as we have described so far, there is a considerable amount of evidence on the effect of genetic variants on CRC chemotoxicity, translation into clinical practice is yet far from routine implementation. For now, guidelines from leading authorities, including the European Medicines Agency (EMA), the Food and Drug Administration (FDA), the private pharmacogenetic consortia, the CPIC, the Royal Dutch Association for the Advancement of Pharmacy-Pharmacogenetics Working Group (DPWG) and the Spanish Agency for Medicines and Health Products (Agencia Española de Medicamentos y Productos Sanitarios, AEMPS) have only produced a very limited list of recommendations (Table 7) [166-170]. 
Table 7. Current CRC pharmacogenetic guidelines for treatment administration.

\begin{tabular}{|c|c|c|c|c|c|c|}
\hline \multirow{2}{*}{ Drug } & \multirow{2}{*}{ Gene } & \multicolumn{5}{|c|}{ Annotation by Drug Regulatory Agencies and Guidelines Recommendations } \\
\hline & & FDA & CPIC & AEMPS & EMA & DPWG \\
\hline Fluoropyrimidines & $D P Y D$ & $\begin{array}{l}\text { Actionable PGx } \\
\text { Withhold or permanently } \\
\text { discontinue treatment in patients } \\
\text { with evidence of acute early-onset } \\
\text { or severe toxicity, which may } \\
\text { indicate near complete or absence } \\
\text { of DPD activity. No dose has been } \\
\text { proven safe for patients with no } \\
\text { DPD activity. There is insufficient } \\
\text { data to recommend a specific dose } \\
\text { in patients with partial } \\
\text { DPD activity [170] }\end{array}$ & $\begin{array}{c}\text { Actionable PGx a } \\
\text { Intermediate metaboliser (individual } \\
\text { with one normal function allele plus } \\
\text { one no function allele or one } \\
\text { decreased function allele, or with } \\
\text { two decreased function } \\
\text { alleles) - decreased DPD activity and } \\
\text { increased risk for severe/fatal ADR. } \\
\text { Reduce starting dose based on AS } \\
\text { followed by titration of dose based } \\
\text { on toxicity or therapeutic drug } \\
\text { monitoring (if available). } \\
\text { AS 1: Reduce dose by 50\% AS 1.5: } \\
\text { Reduce dose by 25-50\% } \\
\text { Poor metaboliser (individual with } \\
\text { two no function alleles, or with one } \\
\text { no function plus one decreased } \\
\text { function allele) - complete DPD } \\
\text { deficiency and increased risk for } \\
\text { severe/fatal ADR. AS 0.5: } \\
\text { Avoid treatment, and in case } \\
\text { alternative agents are not suitable, } \\
\text { strongly reduce starting dose with } \\
\text { early therapeutic drug monitoring. } \\
\text { AS 0: Avoid treatment [167] }\end{array}$ & $\begin{array}{c}\text { Testing required } \\
\text { Test for DPYD genotype } \\
\text { (c.1905+1G>A, c.1679T>G, } \\
\text { c.2846A }>\text { T and } \\
\text { c.1236G }>\text { A/HapB3) and/or } \\
\text { DPD deficiency (measure blood } \\
\text { uracil level) before treatment. } \\
\text { Treatment is contraindicated in } \\
\text { patients with complete DPD } \\
\text { deficiency. In case of partial } \\
\text { DPD deficiency with no } \\
\text { suitable alternative agents, } \\
\text { reduce initial dose and monitor } \\
\text { levels. No concrete reduction } \\
\text { has been established [166] }\end{array}$ & $\begin{array}{l}\text { Testing required }{ }^{\mathrm{b}} \\
\text { Test for the lack of DPD } \\
\text { activity before treatment } \\
\text { (measure blood uracil level, } \\
\text { or check for DPYD } \\
\text { variants-c.1905+1G }>\mathrm{A}, \\
\text { c.1679T }>\mathrm{G}, \mathrm{c} .2846 \mathrm{~A}>\mathrm{T} \text { y } \\
\text { c.1236G }>\mathrm{A} / \mathrm{HapB} 3 \text { ). } \\
\text { Treatment is contraindicated } \\
\text { in patients with complete } \\
\text { DPD deficiency. A reduced } \\
\text { starting dose should be } \\
\text { considered in patients with } \\
\text { partial DPD deficiency [169] }\end{array}$ & - \\
\hline Irinotecan & UGT1A1 & $\begin{array}{l}\text { Actionable PGx }^{\text {a }} \\
\text { Consider reduction in starting } \\
\text { dose for patients homozygous for } \\
\text { the } U G T 1 A 1^{*} 28 \text { allele. The precise } \\
\text { dose reduction is not known and } \\
\text { subsequent dose modifications } \\
\text { should be considered based on } \\
\text { individual patient tolerance } \\
\text { to treatment [170] }\end{array}$ & - & - & - & $\begin{array}{l}\text { Actionable PGx a } \\
\text { Start with } 70 \% \text { of } \\
\text { standard dose. If the } \\
\text { patient tolerates it, } \\
\text { the dose can be } \\
\text { increased, guided by the } \\
\text { neutrophil count [168] }\end{array}$ \\
\hline Cetuximab/panitumumab & $\begin{array}{l}\text { EGFR } \\
\text { KRAS } \\
\text { NRAS }\end{array}$ & $\begin{array}{l}\text { Testing required }^{\mathrm{b}} \\
\text { Determine EGFR expression status } \\
\text { and confirm the absence of an } R A S \\
\text { mutation before treatment [170] }\end{array}$ & - & - & $\begin{array}{l}\text { Testing required } \\
\text { Test } \\
\text { NAS status }(K R A S \text { and } \\
\text { NRAS exons } 2,3 \text { and } 4) \\
\text { before treatment [171] }\end{array}$ & - \\
\hline
\end{tabular}

a: Actionable PGx-it may inform about changes in efficacy, dosage, metabolism or toxicity due to gene/protein/chromosomal variants or phenotypes, or contraindicate a drug in a subset of patients with particular variants/genotypes/phenotypes, without requiring prior testing. b: Testing required-it states that testing should be conducted before using a drug.

This requirement may only be for a subset of patients. 
Pharmacogenetic guidelines from CPIC for the administration of fluoropyrimidines recommend that the DPYD metaboliser status (based on variants rs3918290, rs67376798, rs55886062 and rs56038477) is characterised prior to treatment administration. Poor metabolisers (AS 0-0.5) either: (a) receive an alternative drug; or (b) if 5-FU/capecitabine is still considered the better suited option of treatment, it is recommended to strongly reduce the given dose and accompany with close monitoring. For intermediate metabolisers (AS 1-1.5), a 50\% dose reduction is recommended [156,167]. On the other hand, the FDA only contraindicates the administration of 5-FU/capecitabine in patients with DPD deficiency, but does not directly recommend screening for DPD deficiency before treatment, neither does it distinguish heterozygous nor homozygous DPD-deficient patients (www.pharmgkb.org/gene/PA145/labelAnnotation (accessed on 07 October 2020)) [170].

As for irinotecan treatments, pharmacogenomic testing criteria are merely based on the UGT1A1 genotype (rs3064744). DPWG recommends a 30\% reduction in the standard dose if patients are UGT1A1*28/28 [168], whereas the FDA vaguely recommends dose reduction (www.pharmgkb.org/ chemical/PA450085/labelAnnotation (accessed on 07 October 2020)) [170]).

With the growing knowledge on CRC pharmacogenomics, more guidelines including other genes/variants will most likely be available in the next coming years. For instance, the $A B C$ transporter genes, like $A B C C 1$ and $A B C B 1$, have been quite studied so far and there is good evidence of their relation to the development of ADRs, both by association studies and functional assays.

\section{Limitations in Pharmacogenomic Studies}

In this appraisal, we have presented a comprehensive review of the field of CRC pharmacogenomics, since its early inception to the latest trends. Although remarkable findings have been produced, the road towards widespread clinical implementation is still far from over, and is inherently hindered by some of the limitations that pharmacogenetic analysis encounters. One of the main problems in pharmacogenomic studies is the extensive phenotype heterogeneity. This could be attributable to at least three different factors: (a) heterogeneity in clinical inclusion, i.e., differences in tumour staging and treatment strategies and lines (i.e., the genetic contribution to toxicity may be different in patients that have received FOLFOX as first-line treatment compared to those who have received it as second line); (b) pharmacogenomic data are not kept in a standardised manner, and it is usually hard to find in the patient's clinical record case report forms, including the appropriate scaling, timing and line of treatment, and Eastern Cooperative Oncology Group (ECOG) performance status of the patient (amongst others) should therefore be used to produce robust study designs; and (c) some ADRs, like haematological counts, can be measured quantitatively, whereas others, like diarrhoea, are subject to clinician interpretation. To overcome this, toxicity grading scales such as the Common Terminology Criteria for Adverse Events (CTCAE) should be used across studies [172].

Secondly, the influence of each therapeutical agent alone is hard, if not impossible, to assess, as the great majority of patients undergo combination therapies, and many of the ADRs are shared amongst treatments. This could be due, for instance, to the backbone presence of 5-FU in most settings but could also result from a pleiotropic effect of different drugs.

Thirdly, there has been, in general, a lack of unambiguous association findings. This could be due to the abovementioned phenotypic heterogeneity, but also other factors such as study sample sizes or population stratification issues. For instance, the overwhelming majority of studies reported in this review have been performed exclusively on Caucasian populations, and there are few published works in non-Europeans. Moreover, those that have been published in Asians show considerable differences in the allelic frequencies of the variants. Therefore, validation of findings in cohorts with appropriate statistical power is essential. On this topic, an outstanding example is the Radiogenomics Consortium, which advocates for the standardisation of toxicity data collection derived from radiation treatments. They have published guidelines for STrengthening the Reporting Of Genetic Association studies in Radiogenomics (STROGAR), which allow for multi-institutional approaches towards large-scale 
radiotherapy patient biorepositories and databanks. Indeed, this consortium has already successfully completed several GWAS of radiotherapy toxicity [173-177].

Fourthly, there are no implemented guidelines for the reporting of pharmacogenetic studies. There have been recent efforts to overcome this, including a publication on the STrengthening the Reporting Of Pharmacogenetic Studies (STROPS). This work produces guidelines to standardise pharmacogenetic reporting. This could be essential for the homogenisation of pharmacogenetic data leading to improved systematic reviewing and meta-analyses, hence improving the power and applicability for pharmacogenetic associations [178].

Overall, the evidence gathered so far has brilliantly supported the relevance of pharmacogenomic testing in personalised medicine approaches. Novel genomic technologies such as GWAS and NGS offer unprecedented and affordable access to genomic information that can be assessed to discover novel pharmacogenomic variants related to toxic ADRs $[179,180]$. Pharmacokinetic profiling has proven to be useful for the identification of patients that might benefit from modified treatment strategies and might help improve the prediction value of genetic testing. Cost-effective analyses produced so far have validated the thought that the treatment design should be designed based on pharmacogenomic data, and that these strategies are always cost-effective vs. having to palliate toxicity issues.

Nevertheless, widespread testing is still anecdotic including in regulatory guideline recommendations. Researchers must hence make additional efforts to produce sound and relevant data that can be presented to the regulatory agencies to support pre-treatment testing. Surely, we must continue working in this direction towards a more meaningful implementation of pharmacogenomics in the routine clinical practice.

Author Contributions: Conceptualisation, C.F.-R.; writing—original draft preparation, A.R.S. and C.F.-R.; writing—review and editing, A.R.S., O.M., Á.C. and C.F.-R.; supervision, C.F.-R. and Á.C.; funding acquisition, Á.C. All authors have read and agreed to the published version of the manuscript.

Funding: This research was supported by grant FIS PI 16/01057- ISCIII (to Á.C.), ISCIII PFIS grant FI17/00215 (to A.R.S.) and Fundación Olga Torres (to C.F.-R.).

Conflicts of Interest: The authors declare no conflict of interest.

\section{References}

1. Bray, F.; Ferlay, J.; Soerjomataram, I.; Siegel, R.L.; Torre, L.A.; Jemal, A. Global cancer statistics 2018: Globocan estimates of incidence and mortality worldwide for 36 cancers in 185 countries. CA Cancer J. Clin. 2018, 68, 394-424. [CrossRef] [PubMed]

2. Douillard, J.Y.; Cunningham, D.; Roth, A.D.; Navarro, M.; James, R.D.; Karasek, P.; Jandik, P.; Iveson, T.; Carmichael, J.; Alakl, M.; et al. Irinotecan combined with fluorouracil compared with fluorouracil alone. as first-line treatment for metastatic colorectal cancer: A multicentre randomised trial. Lancet 2000, 355, 1041-1047. [CrossRef]

3. de Gramont, A.; Figer, A.; Seymour, M.; Homerin, M.; Hmissi, A.; Cassidy, J.; Boni, C.; Cortes-Funes, H.; Cervantes, A.; Freyer, G.; et al. Leucovorin and fluorouracil with or without oxaliplatin as first-line treatment in advanced colorectal cancer. J. Clin. Oncol. 2000, 18, 2938-2947. [CrossRef] [PubMed]

4. Van Cutsem, E.; Cervantes, A.; Nordlinger, B.; Arnold, D. The ESMO Guidelines Working Group Metastatic colorectal cancer: ESMO clinical practice guidelines for diagnosis, treatment and follow-up. Ann. Oncol. 2014, 25, iii1-iii9. [CrossRef]

5. Iacovelli, R.; Pietrantonio, F.; Palazzo, A.; Maggi, C.; Ricchini, F.; De Braud, F.; Di Bartolomeo, M. Incidence and relative risk of grade 3 and 4 diarrhoea in patients treated with capecitabine or 5-fluorouracil: A metaanalysis of published trials. Br. J. Clin. Pharmacol. 2014, 78, 1228-1237. [CrossRef] [PubMed]

6. Schwartz, L.H.; Litière, S.; De Vries, E.; Ford, R.; Gwyther, S.; Mandrekar, S.; Shankar, L.; Bogaerts, J.; Chen, A.; Dancey, J.; et al. RECIST 1.1-Update and clarification: From the RECIST committee. Eur. J. Cancer 2016, 62, 132-137. [CrossRef] 
7. Latremouille-Viau, D.; Chang, J.; Guerin, A.; Shi, S.; Wang, E.; Yu, J.; Ngai, C. The economic burden of common adverse events associated with metastatic colorectal cancer treatment in the United States. J. Med. Econ. 2016, 20, 54-62. [CrossRef]

8. Peters, E.J.; Motsinger-Reif, A.; Havener, T.M.; Everitt, L.; Hardison, N.E.; Watson, V.G.; Wagner, M.; Richards, K.L.; Province, M.A.; McLeod, H.L. Pharmacogenomic characterization of US FDA-approved cytotoxic drugs. Pharmacogenomics 2011, 12, 1407-1415. [CrossRef]

9. Watters, J.W.; Kraja, A.; Meucci, M.A.; Province, M.A.; McLeod, H.L. Genome-wide discovery of loci influencing chemotherapy cytotoxicity. Proc. Natl. Acad. Sci. USA 2004, 101, 11809-11814. [CrossRef]

10. Whirl-Carrillo, M.; McDonagh, E.M.; Hebert, J.M.; Gong, L.; Sangkuhl, K.; Thorn, C.F.; Altman, R.B.; Klein, T.E. Pharmacogenomics knowledge for personalized medicine. Clin. Pharmacol. Ther. 2012, 92, 414-417. [CrossRef]

11. Longley, D.B.; Harkin, D.P.; Johnston, P.G. 5-Fluorouracil: Mechanisms of action and clinical strategies. Nat. Rev. Cancer 2003, 3, 330-338. [CrossRef] [PubMed]

12. Food and Drug Administration. Highlights of prescribing information. Capecitabine 2015. Available online: https:/www.accessdata.fda.gov/drugsatfda_docs/label/2015/020896s037lbl.pdf (accessed on 13 November 2020).

13. De Matti, E.; Roncato, R.; Dalle Fratte, C.; Ecca, F.; Toffoli, G.; Cecchin, E. The use of pharmacogenetics to increase the safety of colorectal cancer patients treatedwith fluoropyrimidines. Cancer Drug Resist. 2019, 2, 116-130. [CrossRef]

14. Van Cutsen, E.; Twelves, C.; Cassidy, J.; Allman, D.; Bajetta, E.; Boyer, M.; Bugat, R.; Findlay, M.; Frings, S.; Jahn, M.; et al. Oral capecitabine compared with intravenous fluorouracil plus leucovorin in patients with metastatic colorectal cancer: Results of a large phase III study. J. Clin. Oncol. 2001, 19, 4097-4106. [CrossRef] [PubMed]

15. Food and Drug Administration. Highlights of prescribing information. Oxaliplatin 2002. Available online: https://www.accessdata.fda.gov/drugsatfda_docs/label/2020/021492s016lbl.pdf (accessed on 13 November 2020).

16. Food and Drug Administration. Highlights of prescribing information. Irinotecan 2014. Available online: https://www.accessdata.fda.gov/drugsatfda_docs/label/2014/020571s048lbl.pdf (accessed on 13 November 2020).

17. Food and Drug Administration. Highlights of prescribing information. Cetuximab 2009. Available online: https://www.accessdata.fda.gov/drugsatfda_docs/label/2019/125084s273lbl.pdf (accessed on 13 November 2020).

18. Food and Drug Administration. Highlights of prescribing information. Panitumumab 2015. Available online: http://www.accessdata.fda.gov/drugsatfda_docs/label/2015/125147s200lbl.pdf (accessed on 13 November 2020).

19. Food and Drug Administration. Highlights of prescribing information. Bevacizumab 2017. Available online: https://www.accessdata.fda.gov/drugsatfda_docs/label/2011/125085s225lbl.pdf (accessed on 13 November 2020).

20. Thorn, C.F.; Marsh, S.; Carrillo, M.W.; McLeod, H.L.; Klein, T.E.; Altman, R.B. Pharm GKB summary: Fluoropyrimidine pathways. Pharm. Genom. 2011, 21, 237-242. [CrossRef]

21. Diasio, R.B.; Harris, B.E. Clinical Pharmacokinetics; Lippincott Williams and Wilkins: Philadelphia, PA, USA, 1989.

22. Raymond, E.; Chaney, S.G.; Taamma, A.; Cvitkovic, E. Oxaliplatin: A review of preclinical and clinical studies. Ann. Oncol. 1998, 9, 1053-1071. [CrossRef]

23. Marsh, S.; McLeod, H.; Dolan, E.; Shukla, S.J.; Rabik, C.A.; Gong, L.; Hernandez-Boussard, T.; Lou, X.J.; Klein, T.E.; Altman, R.B. Platinum pathway. Pharm. Genom. 2009, 19, 563-564. [CrossRef]

24. Saltz, L.B.; Cox, J.V.; Blanke, C.; Rosen, L.S.; Fehrenbacher, L.; Moore, M.J.; Maroun, J.A.; Ackland, S.P.; Locker, P.K.; Pirotta, N.; et al. Irinotecan plus Fluorouracil and Leucovorin for Metastatic Colorectal Cancer. N. Engl. J. Med. 2000, 343, 905-914. [CrossRef]

25. Wall, M.E.; Wani, M.C. Discovery to Clinic. Ann. N. Y. Acad. Sci. 1996, 803, 1-12. [CrossRef]

26. Rothenberg, M.L. Topoisomerase I inhibitors: Review and update. Ann. Oncol. 1997, 8, 837-855. [CrossRef]

27. Zhao, B.; Wang, L.; Qiu, H.; Zhang, M.; Sun, L.; Peng, P.; Yu, Q.; Yuan, X. Mechanisms of resistance to anti-EGFR therapy in colorectal cancer. Oncotarget 2016, 8, 3980-4000. [CrossRef]

28. Toffoli, G.; Giodini, L.; Buonadonna, A.; Berretta, M.; De Paoli, A.; Scalone, S.; Miolo, G.; Mini, E.; Nobili, S.; Lonardi, S.; et al. Clinical validity of a DPYD-based pharmacogenetic test to predict severe toxicity to fluoropyrimidines. Int. J. Cancer 2015, 137, 2971-2980. [CrossRef] [PubMed]

29. Offer, S.M.; Wegner, N.J.; Fossum, C.; Wang, K.; Diasio, R.B. Phenotypic profiling of DPYD variations relevant to 5-fluorouracil sensitivity using real-time cellular analysis and in vitro measurement of enzyme activity. Cancer Res. 2013, 73, 1958-1968. [CrossRef] [PubMed] 
30. Henricks, L.M.; Lunenburg†, C.A.; Meulendijks, D.; Gelderblom, H.; Cats, A.; Swen, J.J.; Schellens, J.H.; Guchelaar, H. TranslatingDPYDgenotype into DPD phenotype: Using theDPYDgene activity score. Pharmacogenomics 2015, 16, 1275-1284. [CrossRef] [PubMed]

31. Offer, S.M.; Fossum, C.C.; Wegner, N.J.; Stuflesser, A.J.; Butterfield, G.L.; Diasio, R.B. Comparative Functional Analysis of DPYD Variants of Potential Clinical Relevance to Dihydropyrimidine Dehydrogenase Activity. Cancer Res. 2014, 74, 2545-2554. [CrossRef]

32. Zaanan, A.; Dumont, L.M.; Loriot, M.A.; Taieb, J.; Narjoz, C. Clinical Pharmacology and Therapeutics; CRC Press: Boca Raton, FL, USA, 2014.

33. Nie, Q.; Shrestha, S.; Tapper, E.E.; Trogstad-Isaacson, C.; Bouchonville, K.J.; Lee, A.M.; Wu, R.; Jerde, C.R.; Wang, Z.; Kubica, P.; et al. Quantitative Contribution of rs75017182 to Dihydropyrimidine Dehydrogenase mRNA Splicing and Enzyme Activity. Clin. Pharmacol. Ther. 2017, 102, 662-670. [CrossRef] [PubMed]

34. Meulendijks, D.; Henricks, L.M.; Sonke, G.S.; Deenen, M.J.; Froehlich, T.K.; Amstutz, U.; Largiadèr, C.R.; Jennings, B.A.; Marinaki, A.M.; Sanderson, J.D.; et al. Clinical relevance of DPYD variants c.1679T>G, c.1236G >A/HapB3, and c.1601G > A as predictors of severe fluoropyrimidine-associated toxicity: A systematic review and meta-analysis of individual patient data. Lancet Oncol. 2015, 16, 1639-1650. [CrossRef]

35. Kouwaki, M.; Hamajima, N.; Sumi, S.; Nonaka, M.; Sasaki, M.; Dobashi, K.; Kidouchi, K.; Togari, H.; Wada, Y. Identification of novel mutations in the dihydropyrimidine dehydrogenase gene in a Japanese patient with 5-fluorouracil toxicity. Clin. Cancer Res. 1998, 4, 2999-3004.

36. Falvella, F.S.; Cheli, S.; Martinetti, A.; Mazzali, C.; Iacovelli, R.; Maggi, C.; Gariboldi, M.; Pierotti, M.A.; Di Bartolomeo, M.; Sottotetti, E.; et al. DPD and UGT1A1 deficiency in colorectal cancer patients receiving triplet chemotherapy with fluoropyrimidines, oxaliplatin and irinotecan. Br. J. Clin. Pharmacol. 2015, 80, 581-588. [CrossRef]

37. Madi, A.; Fisher, D.; Maughan, T.S.; Colley, J.P.; Meade, A.M.; Maynard, J.; Humphreys, V.; Wasan, H.; Adams, R.A.; Idziaszczyk, S.; et al. Pharmacogenetic analyses of 2183 patients with advanced colorectal cancer; potential role for common dihydropyrimidine dehydrogenase variants in toxicity to chemotherapy. Eur. J. Cancer 2018, 102, 31-39. [CrossRef]

38. Vreken, P.; Van Kuilenburg, A.B.P.; Meinsma, R.; Van Gennip, A.H. Identification of novel point mutations in the dihydropyrimidine dehydrogenase gene. J. Inherit. Metab. Dis. 1997, 20, 335-338. [CrossRef]

39. O’Donnell, P.H.; Trubetskoy, V.; Nurhussein-Patterson, A.; Hall, J.P.; Nath, A.; Huo, D.; Fleming, G.F.; Ingle, J.N.; Abramson, V.G.; Morrow, P.K.; et al. Clinical evaluation of germline polymorphisms associated with capecitabine toxicity in breast cancer: TBCRC-015. Breast Cancer Res. Treat. 2020, 181, 623-633. [CrossRef] [PubMed]

40. Ruzzo, A.; Graziano, F.; Galli, F.; Galli, F.; Rulli, E.; Lonardi, S.; Ronzoni, M.; Massidda, B.; Zagonel, V.; Pella, N.; et al. Dihydropyrimidine dehydrogenase pharmacogenetics for predicting fluoropyrimidine-related toxicity in the randomised, phase III adjuvant TOSCA trial in high-risk colon cancer patients. Br. J. Cancer 2017, 117, 1269-1277. [CrossRef] [PubMed]

41. Rosmarin, D.; Palles, C.; Pagnamenta, A.; Kaur, K.; Pita, G.; Martin, M.; Domingo, E.; Jones, A.; Howarth, K.; Freeman-Mills, L.; et al. A candidate gene study of capecitabine-related toxicity in colorectal cancer identifies new toxicity variants at DPYD and a putative role for ENOSF1 rather than TYMS. Gut 2015, 64, 111-120. [CrossRef] [PubMed]

42. Pellicer, M.; García-González, X.; García, M.I.; Robles, L.; Grávalos, C.; García-Alfonso, P.; Pachón, V.; Longo, F.; Martínez, V.; Blanco, C.; et al. Identification of new SNPs associated with severe toxicity to capecitabine. Pharmacol. Res. 2017, 120, 133-137. [CrossRef] [PubMed]

43. Meulendijks, D.; Jacobs, B.A.; Aliev, A.; Pluim, D.; Van Werkhoven, E.; Deenen, M.J.; Beijnen, J.H.; Cats, A.; Schellens, J.H. Increased risk of severe fluoropyrimidine-associated toxicity in patients carrying a $\mathrm{G}$ to $\mathrm{C}$ substitution in the first 28-bp tandem repeat of the thymidylate synthase 2 R allele. Int. J. Cancer 2015, 138, 245-253. [CrossRef]

44. Kristensen, M.H.; Pedersen, P.L.; Melsen, G.V.; Ellehauge, J.; Mejer, J. Variants in the dihydropyrimidine dehydrogenase, methylenetetrahydrofolate reductase and thymidylate synthase genes predict early toxicity of 5-fluorouracil in colorectal cancer patients. J. Int. Med. Res. 2010, 38, 870-883. [CrossRef] 
45. Rosmarin, D.; Palles, C.; Church, D.; Domingo, E.; Jones, A.; Johnstone, E.; Wang, H.; Love, S.; Julier, P.; Scudder, C.; et al. Genetic markers of toxicity from capecitabine and other fluorouracil-based regimens: Investigation in the QUASAR2 study, systematic review, and meta-analysis. J. Clin. Oncol. 2014, 32, 1031-1039. [CrossRef]

46. Tsunoda, A.; Nakao, K.; Watanabe, M.; Matsui, N.; Ooyama, A.; Kusano, M. Associations of various gene polymorphisms with toxicity in colorectal cancer patients receiving oral uracil and tegafur plus leucovorin: A prospective study. Ann. Oncol. 2011, 22, 355-361. [CrossRef]

47. Loganayagam, A.; Arenas Hernandez, M.; Corrigan, A.; Fairbanks, L.; Lewis, C.M.; Harper, P.; Maisey, N.; Ross, P.; Sanderson, J.D.; Marinaki, A.M. Pharmacogenetic variants in the DPYD, TYMS, CDA and MTHFR genes are clinically significant predictors of fluoropyrimidine toxicity. Br. J. Cancer 2013, 108, 2505-2515. [CrossRef]

48. Lee, K.H.; Chang, H.J.; Han, S.W.; Oh, D.Y.; Im, S.A.; Bang, Y.J.; Kim, S.Y.; Lee, K.W.; Kim, J.H.; Hong, Y.S.; et al. Pharmacogenetic analysis of adjuvant FOLFOX for Korean patients with colon cancer. Cancer Chemother. Pharm. 2013, 71, 843-851. [CrossRef]

49. Jennings, B.A.; Loke, Y.K.; Skinner, J.; Keane, M.; Chu, G.S.; Turner, R.; Epurescu, D.; Barrett, A.; Willis, G. Evaluating Predictive Pharmacogenetic Signatures of Adverse Events in Colorectal Cancer Patients Treated with Fluoropyrimidines. PLoS ONE 2013, 8, 1-9. [CrossRef] [PubMed]

50. Meulendijks, D.; Henricks, L.M.; Amstutz, U.; Froehlich, T.K.; Largiadèr, C.R.; Beijnen, J.H.; de Boer, A.; Deenen, M.J.; Cats, A.; Schellens, J.H.M. Rs895819 in MIR27A improves the predictive value of DPYD variants to identify patients at risk of severe fluoropyrimidine-associated toxicity. Int. J. Cancer 2016, 138, 2752-2761. [CrossRef] [PubMed]

51. Magdy, T.; Arlanov, R.; Winter, S.; Lang, T.; Klein, K.; Toyoda, Y.; Ishikawa, T.; Schwab, M.; Zanger, U.M. ABCC11/MRP8 polymorphisms affect 5-fluorouracil-induced severe toxicity and hepatic expression. Pharmacogenomics 2013, 14, 1433-1448. [CrossRef] [PubMed]

52. Gonzalez-Haba, E.; García, M.I.; Cortejoso, L.; López-Lillo, C.; Barrueco, N.; García-Alfonso, P.; Alvarez, S.; Jiménez, J.L.; Martín, M.L.; Muñóz-Fernández, M.A.; et al. ABCB1 gene polymorphisms are associated with adverse reactions in fluoropyrimidine-treated colorectal cancer patients. Pharmacogenomics 2010, 11, 1715-1723. [CrossRef] [PubMed]

53. García-González, X.; Cortejoso, L.; García, M.I.; García-Alfonso, P.; Robles, L.; Grávalos, C.; González-Haba, E.; Marta, P.; Sanjurjo, M.; López-Fernández, L.A. Variants in CDA and ABCB1 are predictors of capecitabinerelated adverse reactions in colorectal cancer. Oncotarget 2015, 6, 6422-6430. [CrossRef]

54. Ribelles, N.; Lopez-Siles, J.; Sanchez, A.; Gonzalez, E.; Sanchez, M.; Carabantes, F.; Sanchez-Rovira, P.; Marquez, A.; Duenas, R.; Sevilla, I.; et al. A Carboxylesterase 2 Gene Polymorphism as Predictor of Capecitabine on Response and Time to Progression. Curr. Drug Metab. 2008, 9, 336-343. [CrossRef]

55. Hamzic, S.; Kummer, D.; Milesi, S.; Mueller, D.; Joerger, M.; Aebi, S.; Amstutz, U.; Largiadèr, C.R. Novel Genetic Variants in Carboxylesterase 1 Predict Severe Early-Onset Capecitabine-Related Toxicity. Clin. Pharm. Ther. 2017, 102, 796-804. [CrossRef]

56. Wheeler, H.E.; González-Neira, A.; Pita, G.; De La Torre-Montero, J.C.; Alonso, R.; Lopez-Fernandez, L.A.; Alba, E.; Martín, M.; Dolan, M.E. Identification of genetic variants associated with capecitabine-induced hand-foot syndrome through integration of patient and cell line genomic analyses. Pharm. Genom. 2014, 24, 231-237. [CrossRef]

57. Fernandez-Rozadilla, C.; Cazier, J.B.; Moreno, V.; Crous-Bou, M.; Guinó, E.; Durán, G.; Lamas, M.J.; López, R.; Candamio, S.; Gallardo, E.; et al. Pharmacogenomics in colorectal cancer: A genome-wide association study to predict toxicity after 5-fluorouracil or FOLFOX administration. Pharm. J. 2013, 13, 209-217. [CrossRef]

58. Cecchin, E.; D'Andrea, M.; Lonardi, S.; Zanusso, C.; Pella, N.; Errante, D.; De Mattia, E.; Polesel, J.; Innocenti, F.; Toffoli, G. A prospective validation pharmacogenomic study in the adjuvant setting of colorectal cancer patients treated with the 5-fluorouracil/leucovorin/oxaliplatin (FOLFOX4) regimen. Pharm. J. 2012, 13, 403-409. [CrossRef]

59. Custodio, A.; Moreno-Rubio, J.; Aparicio, J.; Gallego-Plazas, J.; Yaya, R.; Maurel, J.; Higuera, O.; Burgos, E.; Ramos, D.; Calatrava, A.; et al. Pharmacogenetic predictors of severe peripheral neuropathy in colon cancer patients treated with oxaliplatin-based adjuvant chemotherapy: A GEMCAD group study. Ann. Oncol. 2014, 25, 398-403. [CrossRef] [PubMed] 
60. Stoehlmacher, J.; Park, D.J.; Zhang, W.; Yang, D.; Groshen, S.; Zahedy, S.; Lenz, H.J. A multivariate analysis of genomic polymorphisms: Prediction of clinical outcome to 5-FU/oxaliplatin combination chemotherapy in refractory colorectal cancer. Br. J. Cancer 2004, 91, 344-354. [CrossRef] [PubMed]

61. Ruzzo, A.; Graziano, F.; Galli, F.; Giacomini, E.; Floriani, I.; Galli, F.; Rulli, E.; Lonardi, S.; Ronzoni, M.; Massidda, B.; et al. Genetic markers for toxicity of adjuvant oxaliplatin and fluoropyrimidines in the phase III TOSCA trial in high-risk colon cancer patients. Sci. Rep. 2014, 4, 1-7. [CrossRef]

62. Boige, V.; Mendiboure, J.; Pignon, J.P.; Loriot, M.A.; Castaing, M.; Barrois, M.; Malka, D.; Trégouët, D.A.; Bouché, O.; Le Corre, D.; et al. Pharmacogenetic assessment of toxicity and outcome in patients with metastatic colorectal cancer treated with LV5FU2, FOLFOX, and FOLFIRI: FFCD 2000-05. J. Clin. Oncol. 2010, 28, 2556-2564. [CrossRef] [PubMed]

63. Salimzadeh, H.; Lindskog, E.B.; Gustavsson, B.; Wettergren, Y.; Ljungman, D. Association of DNA repair gene variants with colorectal cancer: Risk, toxicity, and survival. BMC Cancer 2020, 20, 1-10. [CrossRef] [PubMed]

64. Ando, Y.; Saka, H.; Ando, M.; Sawa, T.; Muro, K.; Ueoka, H.; Yokoyama, A.; Saitoh, S.; Shimokata, K.; Hasegawa, Y. Polymorphisms of UDP-glucuronosyltransferase gene and irinotecan toxicity: A pharmacogenetic analysis. Cancer Res. 2000, 60, 6921-6926. [PubMed]

65. Onoue, M.; Terada, T.; Kobayashi, M.; Katsura, T.; Matsumoto, S.; Yanagihara, K.; Nishimura, T.; Kanai, M.; Teramukai, S.; Shimizu, A.; et al. UGT1A1*6 polymorphism is most predictive of severe neutropenia induced by irinotecan in Japanese cancer patients. Int. J. Clin. Oncol. 2009, 14, 136-142. [CrossRef] [PubMed]

66. Chen, S.; Laverdiere, I.; Tourancheau, A.; Jonker, D.; Couture, F.; Cecchin, E.; Villeneuve, L.; Harvey, M.; Court, M.H.; Innocenti, F.; et al. A novel UGT1 marker associated with better tolerance against irinotecaninduced severe neutropenia in metastatic colorectal cancer patients. Pharm. J. 2015, 15, 513-520. [CrossRef]

67. Innocenti, F.; Undevia, S.D.; Iyer, L.; Chen, P.X.; Das, S.; Kocherginsky, M.; Karrison, T.; Janisch, L.; Ramírez, J.; Rudin, C.M.; et al. Genetic variants in the UDP-glucuronosyltransferase 1A1 gene predict the risk of severe neutropenia of irinotecan. J. Clin. Oncol. 2004, 22, 1382-1388. [CrossRef]

68. Côté, J.F.; Kirzin, S.; Kramar, A.; Mosnier, J.F.; Diebold, M.D.; Soubeyran, I.; Thirouard, A.S.; Selves, J.; Laurent-Puig, P.; Ychou, M. UGT1A1 polymorphism can predict hematologic toxicity in patients treated with irinotecan. Clin. Cancer Res. 2007, 13, 3269-3275. [CrossRef]

69. Lévesque, É.; Bélanger, A.S.; Harvey, M.; Couture, F.; Jonker, D.; Innocenti, F.; Cecchin, E.; Toffoli, G.; Guillemette, C. Refining the UGT1A haplotype associated with irinotecan-induced hematological toxicity in metastatic colorectal cancer patients treated with 5-fluorouracil/irinotecan-based regimens. J. Pharm. Exp. Ther. 2013, 345, 95-101. [CrossRef]

70. Han, J.-Y.; Lim, H.-S.; Park, Y.H.; Lee, S.Y.; Lee, J.S. Integrated pharmacogenetic prediction of irinotecan pharmacokinetics and toxicity in patients with advanced non-small cell lung cancer. Lung Cancer 2009, 63, 115-120. [CrossRef]

71. Chen, S.; Villeneuve, L.; Jonker, D.; Couture, F.; Laverdière, I.; Cecchin, E.; Innocenti, F.; Toffoli, G.; Lévesque, E.; Guillemette, C. ABCC5 and ABCG1 polymorphisms predict irinotecan-induced severe toxicity in metastatic colorectal cancer patients. Pharm. Genom. 2015, 25, 573-583. [CrossRef]

72. Di Martino, M.T.; Arbitrio, M.; Leone, E.; Guzzi, P.H.; Rotundo, M.S.; Ciliberto, D.; Tomaino, V.; Fabiani, F.; Talarico, D.; Sperlongano, P.; et al. Single nucleotide polymorphisms of ABCC5 and ABCG1 transporter genes correlate to irinotecan-associated gastrointestinal toxicity in colorectal cancer patients: A DMET microarray profiling study. Cancer Biol. Ther. 2011, 12, 780-787. [CrossRef]

73. Li, M.; Seiser, E.L.; Baldwin, R.M.; Ramirez, J.; Ratain, M.J.; Innocenti, F.; Kroetz, D.L. ABC transporter polymorphisms are associated with irinotecan pharmacokinetics and neutropenia. Pharm. J. 2018, 18, 35-42. [CrossRef]

74. De Mattia, E.; Toffoli, G.; Polesel, J.; D’Andrea, M.; Corona, G.; Zagonel, V.; Buonadonna, A.; Dreussi, E.; Cecchin, E. Pharmacogenetics of ABC and SLC transporters in metastatic colorectal cancer patients receiving first-line FOLFIRI treatment. Pharm. Genom. 2013, 23, 549-557. [CrossRef]

75. Hoskins, J.M.; Marcuello, E.; Altes, A.; Marsh, S.; Maxwell, T.; Van Booven, D.J.; Paré, L.; Culverhouse, R.; McLeod, H.L.; Baiget, M. Irinotecan Pharmacogenetics: Influence of Pharmacodynamic Genes. Clin. Cancer Res. 2008, 14, 1788-1796. [CrossRef] 
76. Li, J.; Yu, Q.; Fu, S.; Xu, M.; Zhang, T.; Xie, C.; Feng, J.; Chen, J.; Zang, A.; Cai, Y.; et al. A novel genetic score model of UGT1A1 and TGFB pathway as predictor of severe irinotecan-related diarrhea in metastatic colorectal cancer patients. J. Cancer Res. Clin. Oncol. 2016, 142, 1621-1628. [CrossRef]

77. Takahashi, H.; Sai, K.; Saito, Y.; Kaniwa, N.; Matsumura, Y.; Hamaguchi, T.; Shimada, Y.; Ohtsu, A.; Yoshino, T.; Doi, T.; et al. Application of a Combination of a Knowledge-Based Algorithm and 2-Stage Screening to Hypothesis-Free Genomic Data on Irinotecan-Treated Patients for Identification of a Candidate Single Nucleotide Polymorphism Related to an Adverse Effect. PLoS ONE 2014, 9, e105160. [CrossRef]

78. Won, H.H.; Lee, J.; Park, J.O.; Park, Y.S.; Lim, H.Y.; Kang, W.K.; Kim, J.W.; Lee, S.Y.; Park, S.H. Polymorphic markers associated with severe oxaliplatin-induced, chronic peripheral neuropathy in colon cancer patients. Cancer 2012, 118, 2828-2836. [CrossRef]

79. Etienne-Grimaldi, M.C.; Bennouna, J.; Formento, J.L.; Douillard, J.Y.; Francoual, M.; Hennebelle, I.; Chatelut, E.; Francois, E.; Faroux, R.; El Hannani, C.; et al. Multifactorial pharmacogenetic analysis in colorectal cancer patients receiving 5-fluorouracil-based therapy together with cetuximab-irinotecan. Br. J. Clin. Pharm. 2012, 73, 776-785. [CrossRef]

80. Parmar, S.; Schumann, C.; Rüdiger, S.; Boeck, S.; Heinemann, V.; Kächele, V.; Seeringer, A.; Paul, T.; Seufferlein, T.; Stingl, J.C. Pharmacogenetic predictors for EGFR-inhibitor-associated skin toxicity. Pharm. J. 2013, 13, 181-188. [CrossRef] [PubMed]

81. Dahan, L.; Norguet, E.; Etienne-Grimaldi, M.-C.; Formento, J.-L.; Gasmi, M.; Nanni, I.; Gaudart, J.; Garcia, S.; Ouafik, L.; Seitz, J.-F.; et al. Pharmacogenetic profiling and cetuximab outcome in patients with advanced colorectal cancer. BMC Cancer 2011, 11, 496. [CrossRef]

82. Baas, J.; Krens, L.; Bohringer, S.; Mol, L.; Punt, C.; Guchelaar, H.; Gelderblom, H. Genome wide association study to identify predictors for severe skin toxicity in colorectal cancer patients treated with cetuximab. PLOS ONE 2018, 13, e0208080. [CrossRef]

83. Sibertin-Blanc, C.; Mancini, J.; Fabre, A.; Lagarde, A.; Del Grande, J.; Levy, N.; Seitz, J.F.; Olschwang, S.;

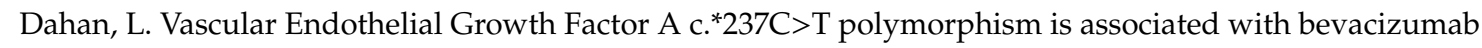
efficacy and related hypertension in metastatic colorectal cancer. Dig. Liver Dis. 2015, 47, 331-337. [CrossRef]

84. Schneider, B.P.; Wang, M.; Radovich, M.; Sledge, G.W.; Badve, S.; Thor, A.; Flockhart, D.A.; Hancock, B.; Davidson, N.; Gralow, J.; et al. Association of vascular endothelial growth factor and vascular endothelial growth factor receptor-2 genetic polymorphisms with outcome in a trial of paclitaxel compared with paclitaxel plus bevacizumab in advanced breast cancer: ECOG 2100. J. Clin. Oncol. 2008, 26, 4672-4678. [CrossRef]

85. Morita, S.; Uehara, K.; Nakayama, G.; Shibata, T.; Oguri, T.; Inada-Inoue, M.; Shimokata, T.; Sugishita, M.; Mitsuma, A.; Ando, Y. Association between bevacizumab-related hypertension and vascular endothelial growth factor (VEGF) gene polymorphisms in Japanese patients with metastatic colorectal cancer. Cancer Chemother. Pharm. 2013, 71, 405-411. [CrossRef]

86. Ma, T.; Zhu, Z.G.; Ji, Y.B.; Zhang, Y.; Yu, Y.Y.; Liu, B.Y.; Yin, H.R.; Lin, Y.Z. Correlation of thymidylate synthase, thymidine phosphorylase and dihydropyrimidine dehydrogenase with sensitivity of gastrointestinal cancer cells to 5-fluorouracil and 5-fluoro-2'-deoxyuridine. World J. Gastroenterol. 2004, 10, 172-176. [CrossRef]

87. Lecomte, T.; Ferraz, J.M.; Zinzindohoué, F.; Loriot, M.A.; Tregouet, D.A.; Landi, B.; Berger, A.; Cugnenc, P.H.; Jian, R.; Beaune, P.; et al. Thymidylate synthase gene polymorphism predicts toxicity in colorectal cancer patients receiving 5-fluorouracil-based chemotherapy. Clin. Cancer Res. 2004, 10, 5880-5888. [CrossRef]

88. Popat, S.; Matakidou, A.; Houlston, R.S. Thymidylate-synthase expression and prognosis in colorectal cancer: A systematic review and meta-analysis. J. Clin. Oncol. 2004, 22, 529-536. [CrossRef]

89. Danenberg, P.V.; Leichman, L.; Lenz, H.J.; Leichman, C.G.; Danenberg, K.D. Thymidylate Synthase Gene and Protein Expression Correlate and Are Associated with Response to 5-Fluorouracil in Human Colorectal and Gastric Tumors. Cancer Res. 1995, 55, 1407-1412.

90. De Mattia, E.; Toffoli, G. C677T and A1298C MTHFR polymorphisms, a challenge for antifolate and fluoropyrimidine-based therapy personalisation. Eur. J. Cancer 2009, 45, 1333-1351. [CrossRef] [PubMed]

91. Chua, W.; Goldstein, D.; Lee, C.K.; Dhillon, H.; Michael, M.; Mitchell, P.; Clarke, S.J.; Iacopetta, B. Molecular markers of response and toxicity to FOLFOX chemotherapy in metastatic colorectal cancer. Br. J. Cancer 2009, 101, 998-1004. [CrossRef] [PubMed]

92. Salvador-Martín, S.; García-González, X.; García, M.I.; Blanco, C.; García-Alfonso, P.; Robles, L.; Grávalos, C.; Pachón, V.; Longo, F.; Martínez, V.; et al. Clinical utility of ABCB1 genotyping for preventing toxicity in treatment with irinotecan. Pharm. Res. 2018, 136, 133-139. [CrossRef] [PubMed] 
93. Glimelius, B.; Garmo, H.; Berglund, Å.; Fredriksson, L.A.; Berglund, M.; Kohnke, H.; Byström, P.; Sørbye, H.; Wadelius, M. Prediction of irinotecan and 5-fluorouracil toxicity and response in patients with advanced colorectal cancer. Pharm. J. 2011, 11, 61-71. [CrossRef] [PubMed]

94. Martin, M.; Martinez, N.; Ramos, M.; Calvo, L.; Lluch, A.; Zamora, P.; Munoz, M.; Carrasco, E.; Caballero, R.; Garcia-Saenz, J.A.; et al. Standard Versus Continuous Administration of Capecitabine in Metastatic Breast Cancer (GEICAM/2009-05): A Randomized, Noninferiority Phase II Trial With a Pharmacogenetic Analysis. Oncologist 2015, 20, 111-112. [CrossRef]

95. Rhodes, K.E.; Zhang, W.; Yang, D.; Press, O.A.; Gordon, M.; Vallböhmer, D.; Schultheis, A.M.; Lurje, G.; Ladner, R.D.; Fazzone, W.; et al. ABCB1, SLCO1B1 and UGT1A1 gene polymorphisms are associated with toxicity in metastatic colorectal cancer patients treated with first-line irinotecan. Drug Metab. Lett. 2007, 1, 23-30. [CrossRef]

96. Mathijssen, R.H.J.; Marsh, S.; Karlsson, M.O.; Xie, R.; Baker, S.D.; Verweij, J.; Sparreboom, A.; McLeod, H.L. Irinotecan pathway genotype analysis to predict pharmacokinetics. Clin. Cancer Res. 2003, 9, 3246-3253.

97. Teft, W.A.; Welch, S.; Lenehan, J.; Parfitt, J.; Choi, Y.H.; Winquist, E.; Kim, R.B. OATP1B1 and tumour OATP1B3 modulate exposure, toxicity, and survival after irinotecan-based chemotherapy. Br. J. Cancer 2015, 112, 857-865. [CrossRef]

98. Cecchin, E.; Corona, G.; Masier, S.; Biason, P.; Cattarossi, G.; Frustaci, S.; Buonadonna, A.; Colussi, A.; Toffoli, G. Carboxylesterase isoform $2 \mathrm{mRNA}$ expression in peripheral blood mononuclear cells is a predictive marker of the irinotecan to SN38 activation step in colorectal cancer patients. Clin. Cancer Res. 2005, 11, 6901-6907. [CrossRef]

99. Cortejoso, L.; López-Fernández, L.A. Pharmacogenetic markers of toxicity for chemotherapy in colorectal cancer patients. Pharmacogenomics 2012, 13, 1173-1191. [CrossRef] [PubMed]

100. Qian, Y.-Y.; Liu, X.-Y.; Wu, Q.; Song, X.; Chen, X.-F.; Liu, Y.-Q.; Pei, D.; Shen, L.-Z.; Shu, Y.-Q. The ERCC1 C118T Polymorphism Predicts Clinical Outcomes of Colorectal Cancer Patients Receiving Oxaliplatin-Based Chemotherapy: A Meta-analysis Based on 22 Studies. Asian Pac. J. Cancer Prev. 2014, 15, 8383-8390. [CrossRef] [PubMed]

101. Etienne-Grimaldi, M.C.; Milano, G.; Maindrault-Gœbel, F.; Chibaudel, B.; Formento, J.L.; Francoual, M.; Lledo, G.; André, T.; Mabro, M.; Mineur, L.; et al. Methylenetetrahydrofolate reductase (MTHFR) gene polymorphisms and FOLFOX response in colorectal cancer patients. Br. J. Clin. Pharm. 2010, 69, 58-66. [CrossRef] [PubMed]

102. McLeod, H.L.; Sargent, D.J.; Marsh, S.; Green, E.M.; King, C.R.; Fuchs, C.S.; Ramanathan, R.K.; Williamson, S.K.; Findlay, B.P.; Thibodeau, S.N.; et al. Pharmacogenetic predictors of adverse events and response to chemotherapy in metastatic colorectal cancer: Results from North American Gastrointestinal Intergroup Trial N9741. J. Clin. Oncol. 2010, 28, 3227-3233. [CrossRef]

103. Gamelin, L.; Capitain, O.; Morel, A.; Dumont, A.; Traore, S.; Anne, L.B.; Gilles, S.; Boisdron-Celle, M.; Gamelin, E. Predictive factors of oxaliplatin neurotoxicity: The involvement of the oxalate outcome pathway. Clin. Cancer Res. 2007, 13, 6359-6368. [CrossRef]

104. Massacesi, C.; Terrazzino, S.; Marcucci, F.; Rocchi, M.B.; Lippe, P.; Bisonni, R.; Lombardo, M.; Pilone, A.; Mattioli, R.; Leon, A. Uridine diphosphate glucuronosyl transferase 1A1 promoter polymorphism predicts the risk of gastrointestinal toxicity and fatigue induced by irinotecan-based chemotherapy. Cancer 2006, 106, 1007-1016. [CrossRef]

105. Iyer, L.; Das, S.; Janisch, L.; Wen, M.; Ramírez, J.; Karrison, T.; Fleming, G.F.; Vokes, E.E.; Schilsky, R.L.; Ratain, M.J. UGT1A1*28 polymorphism as a determinant of irinotecan disposition and toxicity. Pharm. J. 2002, 2, 43-47. [CrossRef]

106. Liu, C.Y.; Chen, P.M.; Chiou, T.J.; Liu, J.H.; Lin, J.K.; Lin, T.C.; Chen, W.S.; Jiang, J.K.; Wang, H.S.; Wang, W.S. UGT1A1*28 polymorphism predicts irinotecan-induced severe toxicities without affecting treatment outcome and survival in patients with metastatic colorectal carcinoma. Cancer 2008, 112, 1932-1940. [CrossRef]

107. Liu, X.; Cheng, D.; Kuang, Q.; Liu, G.; Xu, W. Association of UGT1A1*28 polymorphisms with irinotecan-induced toxicities in colorectal cancer: A meta-analysis in Caucasians. Pharm. J. 2014, 14, 120-129. [CrossRef] 
108. Toffoli, G.; Cecchin, E.; Gasparini, G.; D’Andrea, M.; Azzarello, G.; Basso, U.; Mini, E.; Pessa, S.; De Mattia, E.; Re, G.L.; et al. Genotype-driven phase I study of irinotecan administered in combination with fluorouracil/leucovorin in patients with metastatic colorectal cancer. J. Clin. Oncol. 2010, 28, 866-871. [CrossRef]

109. Marcuello, E.; Páez, D.; Paré, L.; Salazar, J.; Sebio, A.; Del Rio, E.; Baiget, M. A genotype-directed phase I-IV dose-finding study of irinotecan in combination with fluorouracil/leucovorin as first-line treatment in advanced colorectal cancer. Br. J. Cancer 2011, 105, 53-57. [CrossRef] [PubMed]

110. Treenert, A.; Areepium, N.; Tanasanvimon, S. Effects of ABCC2 and SLCO1B1 Polymorphisms on treatment responses in Thai metastatic colorectal cancer patients treated with Irinotecan-based chemotherapy. Asian Pac. J. Cancer Prev. 2018, 19, 2757-2764. [CrossRef] [PubMed]

111. Innocenti, F.; Kroetz, D.L.; Schuetz, E.; Dolan, M.E.; Ramírez, J.; Relling, M.; Chen, P.; Das, S.; Rosner, G.L.; Ratain, M.J. Comprehensive pharmacogenetic analysis of irinotecan neutropenia and pharmacokinetics. J. Clin. Oncol. 2009, 27, 2604-2614. [CrossRef] [PubMed]

112. Riera, P.; Salazar, J.; Virgili, A.C.; Tobeña, M.; Sebio, A.; Gallano, P.; Barnadas, A.; Páez, D. Relevance of CYP3A4*20, UGT1A1*37 and UGT1A1*28 variants in irinotecan-induced severe toxicity. Br. J. Clin. Pharm. 2018, 84, 1389-1392. [CrossRef] [PubMed]

113. Fujikura, K.; Ingelman-Sundberg, M.; Lauschke, V.M. Genetic variation in the human cytochrome P450 supergene family. Pharm. Genom. 2015, 25, 584-594. [CrossRef] [PubMed]

114. Paulík, A.; Grim, J.; Filip, S. Predictors of irinotecan toxicity and efficacy in treatment of metastatic colorectal cancer. Acta Medica 2012, 55, 153-159. [CrossRef]

115. Sunakawa, Y.; Yang, D.; Moran, M.; Astrow, S.H.; Tsuji, A.; Stephens, C.; Zhang, W.; Cao, S.; Takahashi, T.; Denda, T.; et al. Combined assessment of EGFR-related molecules to predict outcome of 1st-line cetuximabcontaining chemotherapy for metastatic colorectal cancer. Cancer Biol. Ther. 2016, 17, 751-759. [CrossRef]

116. Pander, J.; Gelderblom, H.; Antonini, N.F.; Tol, J.; van Krieken, J.H.J.M.; van der Straaten, T.; Punt, C.J.A.; Guchelaar, H.J. Correlation of FCGR3A and EGFR germline polymorphisms with the efficacy of cetuximab in KRAS wild-type metastatic colorectal cancer. Eur. J. Cancer 2010, 46, 1829-1834. [CrossRef]

117. Lambrechts, D.; Moisse, M.; Delmar, P.; Miles, D.W.; Leighl, N.; Escudier, B.; Van Cutsem, E.; Bansal, A.T.; Carmeliet, P.; Scherer, S.J.; et al. Genetic markers of bevacizumab-induced hypertension. Angiogenesis 2014, 17, 685-694. [CrossRef]

118. Etienne-Grimaldi, M.C.; Formento, P.; Degeorges, A.; Pierga, J.Y.; Delva, R.; Pivot, X.; Dalenc, F.; Espié, M.; Veyret, C.; Formento, J.L.; et al. Prospective analysis of the impact of VEGF-A gene polymorphisms on the pharmacodynamics of bevacizumab-based therapy in metastatic breast cancer patients. Br. J. Clin. Pharm. 2011, 71, 921-928. [CrossRef]

119. Le, D.T.; Durham, J.N.; Smith, K.N.; Wang, H.; Bartlett, B.R.; Aulakh, L.K.; Lu, S.; Kemberling, H.; Wilt, C.; Luber, B.S.; et al. Mismatch repair deficiency predicts response of solid tumors to PD-1 blockade. Science 2017, 357, 409-413. [CrossRef] [PubMed]

120. Food and Drug Administration. FDA Grants Accelerated Approval to Ipilimumab for MSI-H or dMMR Metastatic Colorectal Cancer. Available online: https://www.fda.gov/drugs/resources-information-approveddrugs/fda-grants-accelerated-approval-ipilimumab-msi-h-or-dmmr-metastatic-colorectal-cancer (accessed on 30 October 2020).

121. Food and Drug Administration. FDA Approves Pembrolizumab for First-Line Treatment of MSI-H/dMMR Colorectal Cancer. Available online: https:/www.fda.gov/drugs/drug-approvals-and-databases/fdaapproves-pembrolizumab-first-line-treatment-msi-hdmmr-colorectal-cancer (accessed on 30 October 2020).

122. Bins, S.; Basak, E.A.; El Bouazzaoui, S.; Koolen, S.L.W.; De Hoop, E.O.; Van Der Leest, C.H.; Van Der Veldt, A.A.M.; Sleijfer, S.; Debets, R.; Van Schaik, R.H.N.; et al. Association between single-nucleotide polymorphisms and adverse events in nivolumab-treated non-small cell lung cancer patients. Br. J. Cancer 2018, 118, 1296-1301. [CrossRef] [PubMed]

123. Al-Samkari, H.; Snyder, G.D.; Nikiforow, S.; Tolaney, S.M.; A Freedman, R.; Losman, J.-A. Haemophagocytic lymphohistiocytosis complicating pembrolizumab treatment for metastatic breast cancer in a patient with the PRF1A91V gene polymorphism. J. Med. Genet. 2018, 56, 39-42. [CrossRef] [PubMed] 
124. Queirolo, P.; Dozin, B.; Morabito, A.; Banelli, B.; Carosio, R.; Fontana, V.; Ferrucci, P.F.; Martinoli, C.; Cocorocchio, E.; Ascierto, P.A.; et al. CTLA-4 gene variant-1661A $>$ G may predict the onset of endocrine adverse events in metastatic melanoma patients treated with ipilimumab. Eur. J. Cancer 2018, 97, 59-61. [CrossRef]

125. Oguri, T.; Mitsuma, A.; Inada-Inoue, M.; Morita, S.; Shibata, T.; Shimokata, T.; Sugishita, M.; Nakayama, G.; Uehara, K.; Hasegawa, Y.; et al. Genetic polymorphisms associated with oxaliplatin-induced peripheral neurotoxicity in Japanese patients with colorectal cancer. Int. J. Clin. Pharm. Ther. 2013, 51, 475-481. [CrossRef]

126. Terrazzino, S.; Argyriou, A.A.; Cargnin, S.; Antonacopoulou, A.G.; Briani, C.; Bruna, J.; Velasco, R.; Alberti, P.; Campagnolo, M.; Lonardi, S.; et al. Genetic determinants of chronic oxaliplatin-induced peripheral neurotoxicity: A genome-wide study replication and meta-analysis. J. Peripher. Nerv. Syst. 2015, 20, 15-23. [CrossRef]

127. Motsinger-Reif, A.A.; Jorgenson, E.; Relling, M.V.; Kroetz, D.L.; Weinshilboum, R.; Cox, N.J.; Roden, D.M. Genome-wide association studies in pharmacogenomics:successes and lessons. Pharm. Genom. 2013, 23, 1744-6872. [CrossRef]

128. Singleton, A.B.; Hardy, J.; Traynor, B.J.; Houlden, H. Towards a complete resolution of the genetic architecture of disease. Trends Genet. 2010, 26, 438-442. [CrossRef]

129. Manolio, T.A.; Collins, F.S.; Cox, N.J.; Goldstein, D.B.; Hindorff, L.A.; Hunter, D.J.; McCarthy, M.I.; Ramos, E.M.; Cardon, L.R.; Chakravarti, A.; et al. Finding the missing heritability of complex diseases. Nature 2009, 461, 747-753. [CrossRef]

130. Scientific, T.F. Axiom Spain Biobank Array. Available online: http://www.usc.es/cegen/wp-content/uploads/ 2019/08/COL32017-1217-Axiom-Spain-EN_FLR_FINAL.pdf. (accessed on 7 October 2020).

131. Mizzi, C.; Peters, B.; Mitropoulou, C.; Mitropoulos, K.; Katsila, T.; Agarwal, M.R.; Van Schaik, R.H.N.; Drmanac, R.; Borg, J.; Patrinos, G.P. Personalized pharmacogenomics profiling using whole-genome sequencing. Pharmacogenomics 2014, 15, 1223-1234. [CrossRef]

132. Apellániz-Ruiz, M.; Lee, M.Y.; Sánchez-Barroso, L.; Gutiérrez-Gutiérrez, G.; Calvo, I.; García-Estévez, L.; Sereno, M.; García-Donás, J.; Castelo, B.; Guerra, E.; et al. Whole-exome sequencing reveals defective CYP3A4 variants predictive of paclitaxel dose-limiting neuropathy. Proc. Clin. Cancer Res. 2015, 21, 322-328. [CrossRef] [PubMed]

133. Kozyra, M.; Ingelman-Sundberg, M.; Lauschke, V.M. Rare genetic variants in cellular transporters, metabolic enzymes, and nuclear receptors can be important determinants of interindividual differences in drug response. Genet. Med. 2017, 19, 20-29. [CrossRef] [PubMed]

134. Santos, M.; Niemi, M.; Hiratsuka, M.; Kumondai, M.; Ingelman-Sundberg, M.; Lauschke, V.M.; Rodríguez-Antona, C. Novel copy-number variations in pharmacogenes contribute to interindividual differences in drug pharmacokinetics. Genet. Med. 2018, 20, 622-629. [CrossRef] [PubMed]

135. Ingelman-Sundberg, M.; Mkrtchian, S.; Zhou, Y.; Lauschke, V.M. Integrating rare genetic variants into pharmacogenetic drug response predictions. Hum. Genom. 2018, 12, 1-12. [CrossRef] [PubMed]

136. Schaller, L.; Lauschke, V.M. The genetic landscape of the human solute carrier (SLC) transporter superfamily. Hum. Genet. 2019, 138, 1359-1377. [CrossRef] [PubMed]

137. Van Staveren, M.C.; Jan Guchelaar, H.; Van Kuilenburg, A.B.P.; Gelderblom, H.; Maring, J.G. Evaluation of predictive tests for screening for dihydropyrimidine dehydrogenase deficiency. Pharm. J. 2013, 13, 389-395. [CrossRef] [PubMed]

138. Van Kuilenburg, A.B.P.; Häusler, P.; Schalhorn, A.; Tanck, M.W.T.; Proost, J.H.; Terborg, C.; Behnke, D.; Schwabe, W.; Jabschinsky, K.; Maring, J.G. Evaluation of 5-fluorouracil pharmacokinetics in cancer patients with a c.19051G>A Mutation in DPYD by means of a bayesian limited sampling strategy. Clin. Pharm. 2012, 51, 163-174. [CrossRef]

139. Maring, J.G.; Van Kuilenburg, A.B.P.; Haasjes, J.; Piersma, H.; Groen, H.J.M.; Uges, D.R.A.; Van Gennip, A.H.; De Vries, E.G.E. Reduced 5-FU clearance in a patient with low DPD activity due to heterozygosity for a mutant allele of the DPYD gene. Br. J. Cancer 2002, 86, 1028-1033. [CrossRef]

140. Offer, S.M.; Lee, A.M.; Mattison, L.K.; Fossum, C.; Wegner, N.J.; Diasio, R.B. A DPYD Variant (Y186C) in Individuals of African Ancestry Is Associated With Reduced DPD Enzyme Activity. Clin. Pharm. Ther. 2013, 94, 158-166. [CrossRef] 
141. Morel, A.; Boisdron-Celle, M.; Fey, L.; Soulie, P.; Craipeau, M.C.; Traore, S.; Gamelin, E. Clinical relevance of different dihydropyrimidine dehydrogenase gene single nucleotide polymorphisms on 5-fluorouracil tolerance. Mol. Cancer Ther. 2006, 5, 2895-2904. [CrossRef]

142. Van Kuilenburg, A.; Hausler, P.; Schalhorn, A.; Tanck, M.; Proost, J.H.; Terborg, C.; Behnke, D.; Schwabe, W.; Jabschinsky, K.; Maring, J.G. Evaluation of 5-FU pharmacokinetics in cancer patients with DPD deficiency using a Bayesian limited sampling strategy. Ther. Drug Monit. 2011, 33, 478.

143. Zhang, H.; Li, Y.-M.; Zhang, H.; Jin, X. DPYD*5 gene mutation contributes to the reduced DPYD enzyme activity and chemotherapeutic toxicity of 5-FU. Med. Oncol. 2007, 24, 251-258. [CrossRef] [PubMed]

144. Sáez-Belló, M.; Mangas-Sanjuán, V.; Martínez-Gómez, M.A.; López-Montenegro Soria, M.Á.; Climente-Martí, M.; Merino-Sanjuán, M. Evaluation of ABC gene polymorphisms on the pharmacokinetics and pharmacodynamics of capecitabine in colorectal patients: Implications for dosing recommendations. Br. J. Clin. Pharm. 2020, online. [CrossRef] [PubMed]

145. Toffoli, G.; Cecchin, E.; Corona, G.; Russo, A.; Buonadonna, A.; D'Andrea, M.; Pasetto, L.M.; Pessa, S.; Errante, D.; De Pangher, V.; et al. The role of UGT1A1*28 polymorphism in the pharmacodynamics and pharmacokinetics of irinotecan in patients with metastatic colorectal cancer. J. Clin. Oncol. 2006, 24, 3061-3068. [CrossRef] [PubMed]

146. Cecchin, E.; Innocenti, F.; D’Andrea, M.; Corona, G.; De Mattia, E.; Biason, P.; Buonadonna, A.; Toffoli, G. Predictive role of the UGT1A1, UGT1A7, and UGT1A9 genetic variants and their haplotypes on the outcome of metastatic colorectal cancer patients treated with fluorouracil, leucovorin, and irinotecan. J. Clin. Oncol. 2009, 27, 2457-2465. [CrossRef]

147. Labriet, A.; De Mattia, E.; Cecchin, E.; Lévesque, É.; Jonker, D.; Couture, F.; Buonadonna, A.; D’Andrea, M.; Villeneuve, L.; Toffoli, G.; et al. Improved progression-free survival in irinotecan-treated metastatic colorectal cancer patients carrying the HNF1A coding variant p.I27L. Front. Pharm. 2017, 8, 712. [CrossRef]

148. Fujita, K.I.; Nagashima, F.; Yamamoto, W.; Endo, H.; Sunakawa, Y.; Yamashita, K.; Ishida, H.; Mizuno, K.; Matsunaga, M.; Araki, K.; et al. Association of ATP-binding cassette, sub-family C, number 2 (ABCC2) genotype with pharmacokinetics of irinotecan in Japanese patients with metastatic colorectal cancer treated with irinotecan plus infusional 5-fluorouracil/leucovorin (FOLFIRI). Biol. Pharm. Bull. 2008, 31, 2137-2142. [CrossRef]

149. Paoluzzi, L.; Singh, A.S.; Price, D.K.; Danesi, R.; Mathijssen, R.H.J.; Verweij, J.; Figg, W.D.; Sparreboom, A. Influence of genetic variants in UGT1A1 and UGT1A9 on the in vivo glucuronidation of SN-38. J. Clin. Pharm. 2004, 44, 854-860. [CrossRef]

150. Sai, K.; Saeki, M.; Saito, Y.; Ozawa, S.; Katori, N.; Jinno, H.; Hasegawa, R.; Kaniwa, N.; Sawada, J.; Komamura, K.; et al. UGT1A1 haplotypes associated with reduced glucuronidation and increased serum bilirubin in irinotecan-administered Japanese patients with cancer*1. Clin. Pharm. Ther. 2004, 75, 501-515. [CrossRef]

151. De Jong, F.A.; Scott-Horton, T.J.; Kroetz, D.L.; McLeod, H.L.; Friberg, L.E.; Mathijssen, R.H.; Verweij, J.; Marsh, S.; Sparreboom, A. Irinotecan-induced diarrhea: Functional significance of the polymorphic ABCC2 transporter protein. Clin. Pharm. Ther. 2007, 81, 42-49. [CrossRef]

152. de Jong, F.A.; Kehrer, D.F.S.; Mathijssen, R.H.J.; Creemers, G.; de Bruijn, P.; van Schaik, R.H.N.; Planting, A.S.T.; van der Gaast, A.; Eskens, F.A.L.M.; Janssen, J.T.P.; et al. Prophylaxis of Irinotecan-Induced Diarrhea with Neomycin and Potential Role for UGT1A1*28 Genotype Screening: A Double-Blind, Randomized, Placebo-Controlled Study. Oncologist 2006, 11, 944-954. [CrossRef] [PubMed]

153. Minami, H.; Sai, K.; Saeki, M.; Saito, Y.; Ozawa, S.; Suzuki, K.; Kaniwa, N.; Sawada, J.I.; Hamaguchi, T.; Yamamoto, N.; et al. Irinotecan pharmacokinetics/pharmacodynamics and UGT1A genetic polymorphisms in Japanese: Roles of UGT1A1*6 and *28. Pharm. Genom. 2007, 17, 497-504. [CrossRef] [PubMed]

154. Jada, S.R.; Lim, R.; Wong, C.I.; Shu, X.; Lee, S.C.; Zhou, Q.; Goh, B.C.; Chowbay, B. Role of UGT1A1*6, UGT1A1*28 and ABCG2 c.421C>A polymorphisms in irinotecan-induced neutropenia in Asian cancer patients. Cancer Sci. 2007, 98, 1461-1467. [CrossRef] [PubMed]

155. Sai, K.; Kaniwa, N.; Itoda, M.; Saito, Y.; Hasegawa, R.; Komamura, K.; Ueno, K.; Kamakura, S.; Kitakaze, M.; Shirao, K.; et al. Haplotype analysis of ABCB1/MDR1 blocks in a Japanese population reveals genotype-dependent renal clearance of irinotecan. Pharmacogenetics 2003, 13, 741-757. [CrossRef] 
156. Henricks, L.M.; Lunenburg, C.A.T.C.; de Man, F.M.; Meulendijks, D.; Frederix, G.W.J.; Kienhuis, E.; Creemers, G.-J.; Baars, A.; Dezentjé, V.O.; Imholz, A.L.T.; et al. DPYD genotype-guided dose individualisation of fluoropyrimidine therapy in patients with cancer: A prospective safety analysis. Lancet Oncol. 2018, 19, 1459-1467. [CrossRef]

157. Kleibl, Z.; Fidlerova, J.; Kleiblova, P.; Kormunda, S.; Bilek, M.; Bouskova, K.; Sevcik, J.; Novotny, J. Influence of dihydropyrimidine dehydrogenase gene (DPYD) coding sequence variants on the development of fluoropyrimidine-related toxicity in patients with high-grade toxicity and patients with excellent tolerance of fluoropyrimidine-based chemotherapy. Neoplasma 2009, 56, 303-316. [CrossRef]

158. Deenen, M.J.; Meulendijks, D.; Cats, A.; Sechterberger, M.K.; Severens, J.L.; Boot, H.; Smits, P.H.; Rosing, H.; Mandigers, C.M.; Soesan, M.; et al. Upfront Genotyping of DPYD*2A to Individualize Fluoropyrimidine Therapy: A Safety and Cost Analysis. J. Clin. Oncol. 2016, 34, 227-234. [CrossRef]

159. Cortejoso, L.; García-González, X.; García, M.I.; García-Alfonso, P.; Sanjurjo, M.; López-Fernández, L.A. Cost-effectiveness of screening for DPYD polymorphisms to prevent neutropenia in cancer patients treated with fluoropyrimidines. Pharmacogenomics 2016, 17, 979-984. [CrossRef]

160. Murphy, C.; Byrne, S.; Ahmed, G.; Kenny, A.; Gallagher, J.; Harvey, H.; O’Farrell, E.; Bird, B. Cost Implications of Reactive Versus Prospective Testing for Dihydropyrimidine Dehydrogenase Deficiency in Patients with Colorectal Cancer: A Single-Institution Experience. Dose-Response 2018, 16, 16. [CrossRef]

161. Henricks, L.M.; Lunenburg, C.A.; De Man, F.M.; Meulendijks, D.; Frederix, G.W.; Kienhuis, E.; Creemers, G.-J.; Baars, A.; Dezentjé, V.O.; Imholz, A.L.; et al. A cost analysis of upfront DPYD genotype-guided dose individualisation in fluoropyrimidine-based anticancer therapy. Eur. J. Cancer 2019, 107, 60-67. [CrossRef]

162. Gold, H.T.; Hall, M.J.; Blinder, V.; Schackman, B.R. Cost effectiveness of pharmacogenetic testing for uridine diphosphate glucuronosyltransferase $1 \mathrm{~A} 1$ before irinotecan administration for metastatic colorectal cancer. Cancer 2009, 115, 3858-3867. [CrossRef] [PubMed]

163. Obradovic, M.; Mrhar, A.; Kos, M. Cost-effectiveness of UGT1A1 genotyping in second-line, high-dose, once every 3 weeks irinotecan monotherapy treatment of colorectal cancer. Pharmacogenomics 2008, 9, 539-549. [CrossRef] [PubMed]

164. Butzke, B.; Oduncu, F.S.; Severin, F.; Pfeufer, A.; Heinemann, V.; Giesen-Jung, C.; Stollenwerk, B.; Rogowski, W.H. The cost-effectiveness of UGT1A1 genotyping before colorectal cancer treatment with irinotecan from the perspective of the German statutory health insurance. Acta Oncol. 2016, 55, 318-328. [CrossRef] [PubMed]

165. Roncato, R.; Cecchin, E.; Montico, M.; De Mattia, E.; Giodini, L.; Buonadonna, A.; Solfrini, V.; Innocenti, F.; Toffoli, G. Cost Evaluation of Irinotecan-Related Toxicities Associated With the UGT1A1*28 Patient Genotype. Clin. Pharm. Ther. 2017, 102, 123-130. [CrossRef]

166. Agencia Española de Medicamentosy Produtos Sanitarios Fluorouracilo, Capecitabina, Tegafury Flucitosina en Pacientes con Déficit de Dihidropirimidina Deshidrogenasa. Available online: https://www.aemps.gob. es/informa/notasinformativas/medicamentosusohumano-3/seguridad-1/2020-seguridad-1/fluorouracilocapecitabina-tegafur-y-flucitosina-en-pacientes-con-deficit-de-dihidropirimidina-deshidrogenasa/ (accessed on 24 September 2020).

167. Amstutz, U.; Henricks, L.M.; Offer, S.M.; Barbarino, J.; Schellens, J.H.; Swen, J.J.; Klein, T.E.; McLeod, H.L.; Caudle, K.E.; Diasio, R.B.; et al. Clinical Pharmacogenetics Implementation Consortium (CPIC) Guideline for Dihydropyrimidine Dehydrogenase Genotype and Fluoropyrimidine Dosing: 2017 Update. Clin. Pharm. Ther. 2018, 103, 210-216. [CrossRef]

168. The Pharmacogenetics Working Group. UGT1A1: Irinotecan. Available online: https://www.g-standaard.nl/ risicoanalyse/B0001694.PDF (accessed on 24 September 2020).

169. European Medicines Agency. Recommendations on DPD Testing Prior to Treatment with Fluorouracil, Capecitabine, Tegafur and Flucytosine. Available online: https:/www.ema.europa.eu/en/news/emarecommendations-dpd-testing-prior-treatment-fluorouracil-capecitabine-tegafur-flucytosine (accessed on 24 September 2020).

170. Food and Drug Administration. Table of Pharmacogenomic Biomarkers in Drug Labeling. Available online: https://www.fda.gov/media/124784/download (accessed on 24 September 2020).

171. European Medicines Agency. Erbitux (cetuximab). Am. J. Neuroradiol. 2010, 31, 626-627. 
172. Cancer Therapy Evaluation Program. Common Terminology Criteria for Adverse Events (CTCAE).v.5.0. Available online: https://ctep.cancer.gov/protocoldevelopment/electronic_applications/docs/ctcae_v5_quick_ reference_5x7.pdf (accessed on 23 July 2020).

173. Kerns, S.L.; Fachal, L.; Dorling, L.; Barnett, G.C.; Baran, A.; Peterson, D.R.; Hollenberg, M.; Hao, K.; Narzo, A.D.; Ahsen, M.E.; et al. Radiogenomics Consortium Genome-Wide Association Study Meta-Analysis of Late Toxicity After Prostate Cancer Radiotherapy. J. Natl. Cancer Inst. 2020, 112, 179-190. [CrossRef]

174. Barnett, G.C.; Thompson, D.; Fachal, L.; Kerns, S.; Talbot, C.; Elliott, R.M.; Dorling, L.; Coles, C.E.; Dearnaley, D.P.; Rosenstein, B.S.; et al. A genome wide association study (GWAS) providing evidence of an association between common genetic variants and late radiotherapy toxicity. Radiother. Oncol. 2014, 111, 178-185. [CrossRef]

175. Fachal, L.; Gómez-Caamaño, A.; Barnett, G.C.; Peleteiro, P.; Carballo, A.M.; Calvo-Crespo, P.; Kerns, S.L.; Sánchez-García, M.; Lobato-Busto, R.; Dorling, L.; et al. A three-stage genome-wide association study identifies a susceptibility locus for late radiotherapy toxicity at 2q24.1. Nat. Genet. 2014, 46, 891-894. [CrossRef]

176. Kerns, S.L.; Stock, R.G.; Stone, N.N.; Blacksburg, S.R.; Rath, L.; Vega, A.; Fachal, L.; Gómez-Caamaño, A.; De Ruysscher, D.; Lammering, G.; et al. Genome-wide association study identifies a region on chromosome $11 q 14.3$ associated with late rectal bleeding following radiation therapy for prostate cancer. Radiother. Oncol. 2013, 107, 372-376. [CrossRef]

177. Kerns, S.L.; Dorling, L.; Fachal, L.; Bentzen, S.; Pharoah, P.D.; Barnes, D.R.; Gómez-Caamaño, A.; Carballo, A.M.; Dearnaley, D.P.; Peleteiro, P.; et al. Meta-analysis of Genome Wide Association Studies Identifies Genetic Markers of Late Toxicity Following Radiotherapy for Prostate Cancer. EBioMedicine 2016, 10, 150-163. [CrossRef] [PubMed]

178. Richardson, M.; Kirkham, J.; Dwan, K.; Sloan, D.J.; Davies, G.R.; Jorgensen, A.L. STrengthening the Reporting of Pharmacogenetic Studies: Development of the STROPS guideline. PLoS Med. 2020, 17, e1003344. [CrossRef]

179. Hegde, M.; Santani, A.; Mao, R.; Ferreira-Gonzalez, A.; Weck, K.E.; Voelkerding, K.V. Development and validation of clinical whole-exome and whole-genome sequencing for detection of germline variants in inherited disease. Arch. Pathol. Lab. Med. 2017, 141, 798-805. [CrossRef] [PubMed]

180. Zhou, Y.; Fujikura, K.; Mkrtchian, S.; Lauschke, V.M. Computational methods for the pharmacogenetic interpretation of next generation sequencing data. Front. Pharm. 2018, 9, 1-17. [CrossRef]

Publisher's Note: MDPI stays neutral with regard to jurisdictional claims in published maps and institutional affiliations.

(C) 2020 by the authors. Licensee MDPI, Basel, Switzerland. This article is an open access article distributed under the terms and conditions of the Creative Commons Attribution (CC BY) license (http://creativecommons.org/licenses/by/4.0/). 